\title{
Willingness to pay for contraceptive vaginal rings in Nigeria
}

Salisu Mohammed Ishaku

Population Council

Ayodeji Oginni

Population Council

Godwin Unumeri

Population Council

Deepa Rajamani

Population Council

Follow this and additional works at: https://knowledgecommons.popcouncil.org/departments_sbsr-rh

Part of the Demography, Population, and Ecology Commons, Family, Life Course, and Society Commons, International Public Health Commons, and the Women's Health Commons How does access to this work benefit you? Let us know!

\section{Recommended Citation}

Ishaku, Salisu Mohammed, Ayodeji Oginni, Godwin Unumeri, and Deepa Rajamani. 2015. "Willingness to pay for contraceptive vaginal rings in Nigeria." Abuja: Population Council. 


\section{WILLINGNESS TO PAY FOR CONTRACEPTIVE VAGINAL RINGS IN NIGERIA}

Salisu Ishaku Ayodeji Babatunde Oginni Godwin Unumeri Deepa Rajamani 


\section{Population \\ Ideas. Evidence. Impact.}

The Population Council confronts critical health and development issues-from stopping the spread of HIV to improving reproductive health and ensuring that young people lead full and productive lives. Through biomedical, social science, and public health research in 50 countries, we work with our partners to deliver solutions that lead to more effective policies, programs, and technologies that improve lives around the world. Established in 1952 and headquartered in New York, the Council is a nongovernmental, nonprofit organization governed by an international board of trustees.

Population Council

House 4, No. 16b, POW Mafemi Crescent

Utako District

Abuja, Nigeria

Tel: +234 8067787750

popcouncil.org

Suggested citation: Ishaku, Salisu, Ayodeji Babatunde Oginni, Godwin Unumeri, and Deepa Rajamani. 2015. "Willingness to Pay for Contraceptive Vaginal Rings in Nigeria." Abuja, Nigeria: Population Council.

(c) 2015 The Population Council, Inc. 


\section{Table of Contents}

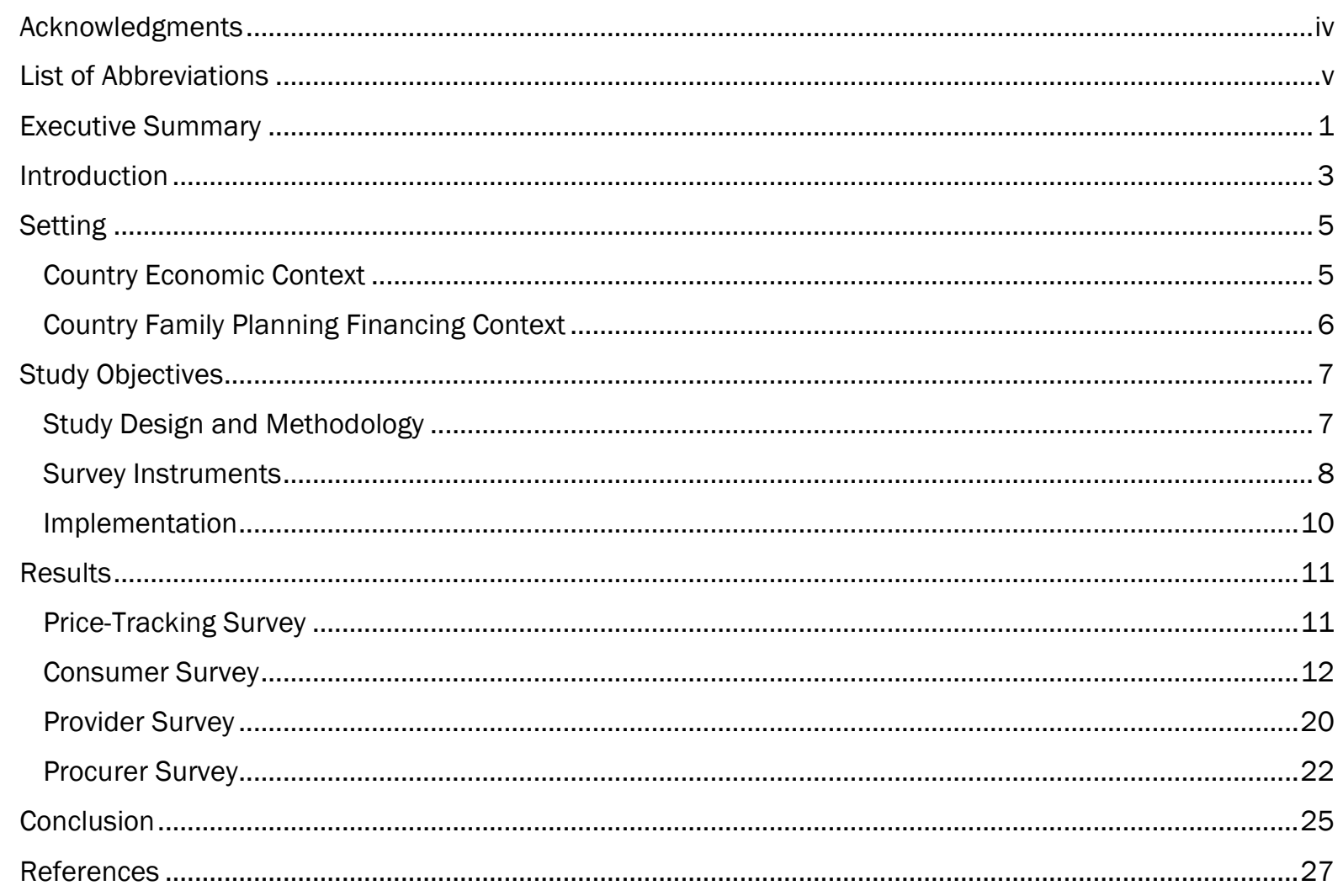




\section{Acknowledgments}

This Willingness to Pay for Contraceptive Vaginal Rings in Nigeria study was made possible by the generous support of the Bill and Melinda Gates Foundation (BMGF). The contents of this report are the sole responsibility of the Population Council and do not necessarily reflect the views of the Bill \& Melinda Gates Foundation. We also acknowledge all stakeholders (public, private, and nonprofit organizations) and individuals who provided valuable input in study design or implementation. Successful completion of the study would not have been possible without the dedication of service providers in the participating health facilities. We further acknowledge all study participants, who gave of their time and provided valuable information during the course of the study. 


\section{List of Abbreviations}

\begin{tabular}{|c|c|}
\hline BMGF & Bill \& Melinda Gates Foundation \\
\hline CHEW & Community Health Extension Worker \\
\hline $\mathrm{CHO}$ & Community Health Officer \\
\hline CiSFP & Civil Society for Family Planning \\
\hline COGS & Cost of Goods \\
\hline CPR & Contraceptive Prevalence Rate \\
\hline CRS & Catholic Relief Services \\
\hline CVR & Contraceptive Vaginal Ring \\
\hline DfID & United Kingdom Department for International Development \\
\hline DKT & Deep K. Tyagi \\
\hline ECP & Emergency Contraceptive Pill \\
\hline EML & Essential Medicines List \\
\hline FCT & Federal Capital Territory \\
\hline FCTHREC & Federal Capital Territory Health Research Ethics Committee \\
\hline $\mathrm{FMoH}$ & Federal Ministry of Health \\
\hline FP & Family Planning \\
\hline GDP & Gross Domestic Product \\
\hline ICAF & International Contraceptive Access Foundation \\
\hline IUD & Intrauterine Contraceptive Device \\
\hline JSI & John Snow International \\
\hline LNG-IUS & Levonorgestrel Intrauterine System \\
\hline MSI & Marie Stopes International \\
\hline NAFDAC & National Agency for Food and Drug Administration and Control \\
\hline PPFA & Planned Parenthood Federation of America \\
\hline $\mathrm{PQ}$ & Prequalification \\
\hline PVR & Progesterone Vaginal Ring \\
\hline $\mathrm{RH}$ & Reproductive Health \\
\hline SFH & Society for Family Health \\
\hline TMA & Total Market Approach \\
\hline TFR & Total Fertility Rate \\
\hline UNFPA & United Nations Population Fund \\
\hline URHI & Urban Reproductive Health Initiative \\
\hline USAID & United States Agency for International Development \\
\hline WHO & World Health Organization \\
\hline WTP & Willingness to Pay \\
\hline
\end{tabular}





\section{Executive Summary}

During the last two decades, Nigeria's Contraceptive Prevalence Rate (CPR) for modern methods remained at 10\% (NPC and ICF International 2014), one of the lowest rates in sub-Saharan Africa. Following the renewed global commitments culminating in the 2012 London Summit on Family Planning with promises to reach an additional 120 million new users of quality modern contraceptives worldwide, Nigeria's Federal Ministry of Health (FMoH) in collaboration with reproductive health $(\mathrm{RH})$ stakeholders set an ambitious new target of raising Nigeria's CPR to $36 \%$ by 2018. One of the ways to accomplish this goal is by meeting the contraceptive needs of women in the immediate postpartum period and beyond. Currently, unmet need for contraception in the postpartum period is $65 \%$ as opposed to $16 \%$ for regular use (NPC and ICF International 2014). Consequently, attention is being focused on making proven and effective contraceptive methods more available and affordable for postpartum use by including in the methods newer technologies that are breastfeeding-friendly. The Progesterone Vaginal Ring (PVR) holds much promise as an effective family planning method specifically geared for breastfeeding women. For use beyond the postpartum period, an investigational long-acting Contraceptive Vaginal Ring (CVR) is currently being developed. As a prelude to introducing the rings in sub-Saharan Africa, the Population Council, with funding from the Bill and Melinda Gates Foundation (BMGF) and the United States Agency for International Development (USAID), conducted a "Willingness to Pay" (WTP) study in Kenya, Nigeria, and Senegal. In order to better understand how the rings could be placed within an equity framework and achieve an optimized service environment, we ensured that both consumers' and providers' preferences, as well as procurers' priorities, were factored into the introductory process. This informed the conduct of this "Willingness to Pay, Provide, and Procure" exercise in these three subSaharan African countries.

Key findings from the study in Nigeria include:

- Prospective consumers, providers, and procurers expressed support and interest in contraceptive vaginal rings (CVRs). Frequently expressed opinions were that the PVR (and the one-year CVR) are a welcome development that would add value to the postpartum family planning landscape, widen contraceptive options for women, enhance child spacing, and prevent unintended pregnancies.

- Consumers are willing to pay for the PVR irrespective of the sector where they access their contraceptive commodities. At a price point of US\$1.70 (N300), more than $75 \%$ of consumers are willing to pay for the PVR in the public, private nonprofit, and commercial sectors. In the public sector, willingness to pay declines at prices over N300. However, in the private sector (nonprofit and commercial), a significant proportion of women are willing to purchase the PVR at higher prices. 
- Although the price of the PVR is a determinant of consumer demand, respondents also indicated other factors such as the desire to avoid unintended pregnancy and the ability to use modern contraceptives as being important to their decision-making. The importance of wanting to avoid unwanted pregnancy is clearly reflected in the market as evidenced by the high median cost of emergency contraceptive (EC) pills (US\$27) in the private sector.

- Consumers were willing to pay for the one-year CVR as well. The analysis indicates a feasible price point of US\$9 $(\mathrm{N} 1,500)$ with a demonstrated willingness to pay across all three sectors. At this price, over $65 \%$ are willing to pay in the public sector and over $80 \%$ in the private nonprofit and commercial sectors.

- The potential for innovative pricing mechanisms, especially for public-sector consumers, will need to be explored. The mechanism would leverage existing government subsidies so that consumers pay a small portion of the price with financing covering the rest.

- Providers across all three sectors indicated the importance of including the PVR and the oneyear CVR in the method mix. Their responses also highlighted the importance of orientation and education of potential providers to ensure their successful integration when eventually registered.

- The procurement, pricing, and quality assurance systems are robust in Nigeria. The PVR (and the one-year CVR), when introduced, could easily feed into the existing structures and obviate the need for establishing parallel procurement, pricing, and quality assurance systems for the PVR and the one-year CVR.

In terms of utilization, the results generated will inform and guide next steps about product introduction. Specifically, the findings of this study will be integrated with results from a market segmentation exercise conducted earlier to develop a pricing model for the PVR. The price will reflect not only the cost of goods (COGS) and cost of product introduction (training, educational material, marketing and branding, demand creation) but also the benefits to the health system (e.g., limited need for infrastructure and equipment, potential for multiple service outlets and health cadres). The results will also be useful to refine PVR market segmentation and tailor specific strategies for product introduction, including innovative financing approaches. 


\section{Introduction}

During the last two decades, the contraceptive prevalence rate (CPR) for modern methods has remained at 10\% in Nigeria (NPC and ICF International 2014), one of the lowest rates in sub-Saharan Africa. Following the renewed global commitments culminating in the 2012 London Summit on Family Planning, ${ }^{1}$ which aims at reaching an additional 120 million new users with quality modern contraceptive methods by the year 2020, the Federal Ministry of Health (FMoH) in collaboration with reproductive health stakeholders in Nigeria unveiled the Nigeria Family Planning Blueprint with an ambitious new target of raising the contraceptive prevalence rate to $36 \%$ by $2018 .^{2}$ This scale-up plan will help avert 1.6 million unintended pregnancies, as well as 400,000 infant and 700,000 child deaths, by the year 2018 at an estimated cost of US $\$ 603$ million.

An integral part of this commitment involves meeting the contraceptive needs of women in the immediate postpartum period and beyond with the help of expanded social marketing services. Currently, the unmet need for contraception in the postpartum period is $65 \%$ as opposed to $16 \%$ for regular use (NPC and ICF International 2014). Consequently, attention is now being focused on making available and accessible proven effective contraceptives for postpartum use. Contraceptive Vaginal Rings (CVRs), as a new product category, hold a lot of potential as an effective family planning method for women throughout their reproductive health life cycle. As a self-initiated method that does not require daily action by the user or significant health system infrastructure for service delivery, vaginal rings can be a great addition to the existing method mix for modern contraception.

The Progesterone Vaginal Ring (PVR) is designed exclusively for addressing the postpartum family planning needs of breastfeeding women. While the PVR is already being used by women in nine countries in Latin America, women in sub-Saharan Africa, where breastfeeding is almost universal, have no access to this technology. To expand access in this region, the Population Council, with funding from the Bill \& Melinda Gates Foundation (BMGF) and the United States Agency for International Development (USAID), conducted various pre-introductory activities in sub-Saharan Africa where women practice prolonged lactation and also have a high unmet need for postpartum family planning of up to $65 \%$ in many countries (Sonalkar et al. 2013). The assessment of "Willingness to Pay" (WTP) for the PVR was conducted to understand economic factors that may determine its uptake and use. In the case of contraceptives, WTP informs about the value that people attach to the benefits of various contraceptives, especially their willingness and intentions to purchase these contraceptives at various hypothetical prices. The study provides new knowledge on the maximum amount of money that consumers are willing to spend for the PVR and a related ring, the one-year CVR, from various service sectors (public, private nonprofit, and private commercial).

Currently, Nigerian women obtain their contraceptive methods from both the public and private sectors (nonprofit and commercial). A range of methods, including intrauterine contraceptive devices (IUDs), implants, injectables, surgical tubal occlusion, and vasectomy are available for postpartum use through Nigeria's family planning policy. However, while contraceptive products are free in the public sector (with minimum allowable fees charged to cover for the costs of consumables), they are

\footnotetext{
${ }^{1}$ FP2020: http://progress.familyplanning2020.org/

2 Health Policy Project, Nigeria Family Planning Blueprint (Scale-Up Plan): http://www.healthpolicyproject.com/index.cfm?ID=topics-FP2020.
} 
not free in the private sector, which provides $60 \%$ of contraceptive services in the country (NPC and ICF International 2014). Ever-increasing changes in the funding landscape have prompted governments to explore "total market" solutions. The Total Market Approach (TMA) identifies specific roles for the public and private sectors to meet the family planning needs of the population. Specifically, the TMA focuses on ensuring that free or subsidized contraceptives are available to the needy and poor, while social marketing channels and other private commercial sales of contraceptives cater to those who are able to pay. This approach can help ensure equity and sustainability of products and services over time and also manage funding shortfalls. Although contraceptive commodities are free of charge in the public sector, commodity stock-outs are frequent and so the private sector plays a dominant role in meeting women's contraceptive needs.

The Nigeria Family Planning Blueprint includes strategies on service delivery, supply-chain management, demand generation and behavior-change communications, and financing. By investigating consumers' willingness to pay for the ring, providers' willingness to provide, and procurers' willingness to procure the ring in the three sectors that serve the total reproductive health market in Nigeria, this study can inform programmatic interventions to contribute to these strategies. A previously concluded market-segmentation exercise for vaginal rings provides us with the knowledge of the various customer segments we will be serving when we introduce vaginal rings into Nigeria's family planning (FP) method mix. By matching different types of providers and services with their appropriate target segments, we can promote effective intersectoral coordination and help the Nigerian government better allocate resources to meet its FP2020 goals and beyond. In the PVR introduction pathway, this study offers a reliable way of making evidence-based pricing decisions for a new FP product and designing programs to achieve a total market solution for balancing the scales of sustainability and cost recovery. 


\section{Setting}

\section{COUNTRY ECONOMIC CONTEXT}

Although Nigeria now has the largest economy in Africa based on its current GDP (Africa Progress Panel 2015), the poverty rate in the country is one of the highest in the region with up to $61 \%$ of the population living on less than US\$1 per day (NBS 2012). Categorized as a lower-middle-income economy, Nigeria is driven almost entirely by its thriving petroleum sector, which is the twelfth largest in the world. More than $90 \%$ of foreign exchange earnings come from petroleum products, while the rest of the economy is mostly agrarian. The recent fall in the price of oil in the international market has implications for public expenditures on social welfare programs including health. Nigeria has been growing at $6-8 \%$ annually over the past decade but now needs to achieve even higher job-led growth rates to make a dent in poverty. A key challenge facing Nigeria is the diversification of its economy and the reduction of heavy reliance on oil, which makes the country vulnerable to commodity price volatility. However, Nigeria's short-term economic outlook has improved in 2014 and growing government revenues indicate macroeconomic stability and positive growth prospects. Recent World Bank assessments highlight the decline in poverty levels; poverty is much lower in urban areas $(12.6 \%)$ than in rural areas (44.9\%). ${ }^{3}$ After a minor slump in 2012, GDP growth increased from 5.5\% in 2013 to $6.3 \%$ in 2014. Inflation has remained on a downward trend since 2011 with the Consumer Price Index (CPI) inflation rate falling within the $8 \%$ range. While the unemployment rate is about $10 \% 4$ and scarcity of jobs continues to be an economic problem, rapid urbanization leading to higher connectivity with larger markets is having a positive impact on the economy.

As of 2014, the per capita household final consumption expenditure (the market value of all goods and services, including durable products such as cars, washing machines, and home computers purchased by households) in Nigeria is on an upward trend reaching US $\$ 616^{5}$ and the gross national income per capita remains stable at around US $\$ 2,970$ (current US\$). In 2013, expenditure on private health was $2.8 \%$ of GDP, which includes direct household (out-of-pocket) spending, private insurance, and charitable donations by private corporations, increasing from $2.3 \%$ in 2012 . Public health expenditure ${ }^{6}$ was $1.1 \%$ of GDP in 2013 and has remained th this level since 2011 . Total health expenditure ${ }^{7}$ has risen steadily from $3.4 \%$ of GDP in 2012 to 3.9\% in 2013.

As Nigeria has a three-tier system of government (federal, state, and local) with different revenue bases, there is potential for program priorities to differ between the three levels of administration with implications for how social programs are planned and implemented. This may affect harmonization of social investment including procurement of reproductive health and family planning commodities especially for the public sector.

\footnotetext{
3 World Bank: Nigeria Economic Report (www.worldbank.org).

4 The internationally accepted ILO definition of unemployment includes members of the active labor population who are looking for work and are available for work, but who are not working, during a previous reference period (often one week).

5 Data reported in constant 2005 US dollars. Source: World Bank national accounts data, and OECD national accounts data files.

${ }^{6}$ Public health expenditure consists of recurrent and capital spending from government (central and local) budgets, external borrowings and grants (including donations from international agencies and nongovernmental organizations), and social (or compulsory) health insurance funds.

${ }^{7}$ Total health expenditure is the sum of public and private health expenditure. It covers the provision of health services (preventive and curative), family planning activities, nutrition activities, and emergency aid designated for health, but does not include provision of water and sanitation.
} 
TABLE 1 Cost of living snapshot in Abuja, Nigeria

\begin{tabular}{l|c|c}
\hline Commodity & Quantity & Average Price (US\$) \\
\hline Milk & 1 gallon & 6.7 \\
\hline Bread & 1 pound & 1.4 \\
\hline Eggs & 1 dozen & 2.0 \\
\hline Onions & 1 pound & 1.1 \\
\hline Beef & 1 pound & 2.1 \\
\hline Gasoline & 1 gallon & 1.7 \\
\hline
\end{tabular}

Source: www.numbeo.com.

\section{COUNTRY FAMILY PLANNING FINANCING CONTEXT}

In Nigeria, family planning financing was entirely donor-driven until 2011 when the Federal Government of Nigeria committed to providing US\$3 million annually from 2011 to 2015 for procurement of contraceptives for the public sector. Following the London summit in 2012, the Nigerian government made a further pledge of providing an additional US $\$ 8.3$ million for the same reasons. The United Nations Population Fund (UNFPA) is the leading procurer of contraceptives for the public sector, while USAID and the United Kingdom Department for International Development (DfID) provide support for the private sector (Tien et al. 2009).

Investments from other development partners play a supplementary role. For example, from 2009 to 2015, BMGF invested in providing contraceptives (oral contraceptives, injectables, implants, intrauterine devices) and services in urban areas through its Urban Reproductive Health Initiative (URHI), which was recently renewed. URHI addresses challenges on the supply and demand side of contraceptive use. The Society for Family Health (SFH) and DKT International8 are the leading social franchising organizations that distribute reproductive health commodities in the private sector at subsidized prices, thus serving a market segment that has limited ability to pay for services/products.

Available methods for postpartum women include injectables, condoms, progestin-only pills, and the lactational amenorrhea method (LAM), with LAM being the most commonly used during this period (Borda and Winfrey 2010). Data from the Nigeria DHS 2013 suggests that the major sources of modern contraceptive methods for women are private health facilities, which supply $60 \%$, followed by public facilities at $29 \%$.

Within the public sector, all contraceptives are offered free of charge by policy, but commodity stockouts are a frequent problem. This, coupled with service-fees, limits the utility of this policy because methods are either not available or service fees are prohibitive. Consequently, a majority of users obtain their contraceptives from the private sector at open market prices. The median cost of modern contraceptives for women who paid for the last method they obtained ranged from about US $\$ 62$ for surgical contraception to less than US $\$ 1$ each for pills and male condoms (NPC and ICF Macro 2009). The active role played by both the private and public sector in providing family planning services indicates the potential for utilizing a total market solution for PVR introduction.

8 DKT International is a social marketing organization named after Deep K. Tyagi, Assistant Commissioner of Family Planning in charge of the public motivation and education aspects of India's Family Planning Program. 


\section{Study Objectives}

The objectives of this study are as follows:

- Obtain a reliable estimate of consumers' demand for the PVR in Nigeria by studying the effect of price on demand;

- Assess the "Willingness to Provide" by family planning providers and "Willingness to Procure" by procurers;

- Facilitate evidence-based pricing for the PVR in the three sectors of interest-public, private nonprofit, and private commercial; and

- Explore respondents' Willingness to Pay for future vaginal rings (including long-acting, reversible options for nonbreastfeeding women) to assess potential demand and to design access strategies.

\section{STUDY DESIGN AND METHODOLOGY}

A cross-sectional study was conducted in three countries in sub-Saharan Africa (Kenya, Nigeria, and Senegal). The study used a multidimensional and multisectoral approach, which examined the willingness to pay for the PVR in the three countries.

Stakeholder-driven approach to WTP: In this approach (see Figure 1), we identified three actors in the PVR WTP assessment landscape: potential consumers, providers, and procurers. We explored the three dimensions of WTP (Willingness to Pay, Willingness to Provide, and Willingness to Procure) by incorporating the voices of these three stakeholders in the data-collection tools.

Sector-driven approach to WTP: Using the guiding principles of improved access, efficient use of public resources, and increased equity, we explored a potential total market model for the PVR by exploring the views and expectations of different sectors that serve the family planning customersthe public, private nonprofit, and private commercial sectors.

A previously conducted market-segmentation exercise based on DHS data revealed three broad segments of potential PVR customers (Obare et al. 2014). Based on the analysis of the socioeconomic profiles of these segments, the first segment denoted as "Easy Switchers" (urban, educated women from rich households) presents the group with potentially the highest WTP, while the other two segments-“Remote First-Timers" (rural, poorly educated women from the poorest households) and "Growth Feeders" (young women with a future need for the PVR)-present potentially decreasing levels of WTP. By utilizing a stakeholder-driven multisectoral approach to assess users' WTP, this study will help develop affordable yet competitive pricing strategies for the PVR. The aim of a TMA is to improve the performance of health systems by delivering the highest degree of effectiveness, equity, and efficiency with the help of coordinated activities across the three sources of supply. The study findings will help us formulate distribution strategies to match the potential PVR consumer segments to the sectors that can best serve them, adopting a total market model. 
FIGURE 1 THREE DIMENSIONS OF WTP FOR THE PVR-WILLINGNESS TO PAY, PROVIDE, AND PROCURE

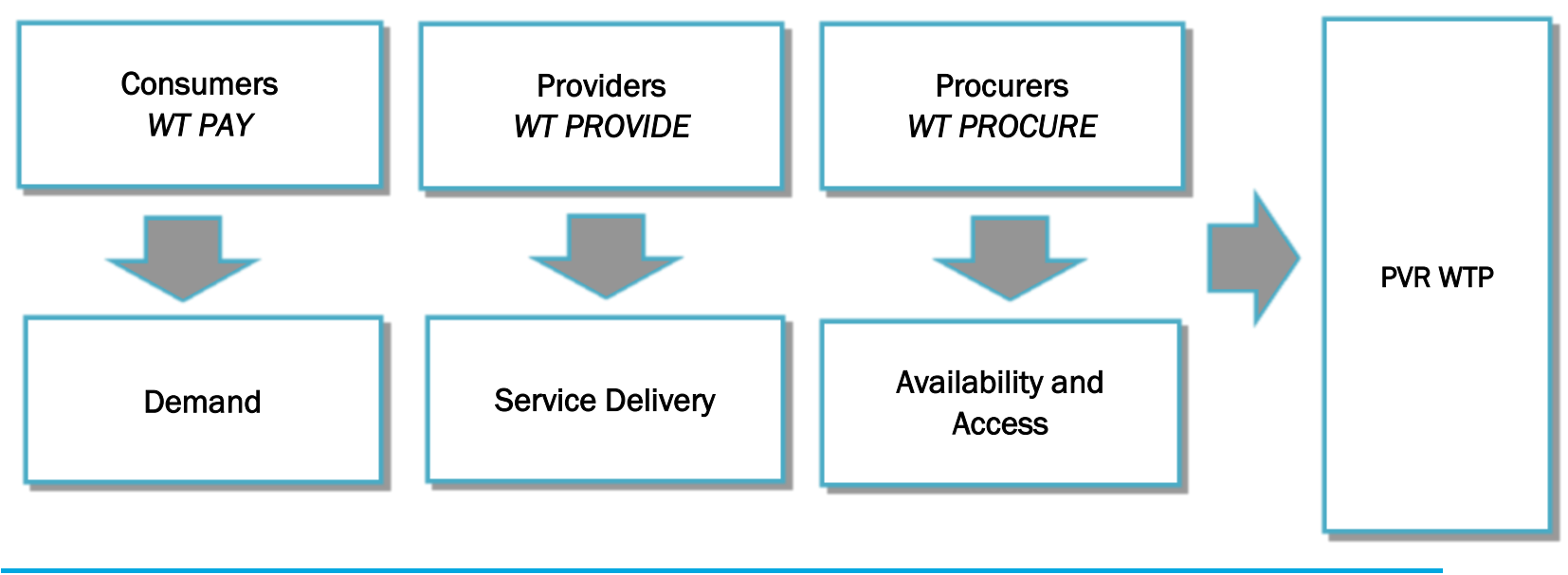

\section{SURVEY INSTRUMENTS}

Specific survey instruments were designed for targeted respondents. Table 2 summarizes the survey tools and methodology used.

TABLE 2 Study design, methodology, and scope

\begin{tabular}{l|l|l}
\hline Stakeholder & Survey Instrument & Target Respondents \\
\hline Consumers & $\begin{array}{l}\text { a) WT Pay Survey } \\
\text { b) Price-Tracking } \\
\text { Survey }\end{array}$ & $\begin{array}{l}\text { a) Potential consumers (women 18-49 years of age) } \\
\text { b) Pharmacists; facilities in charge at social- } \\
\text { marketing outlets; public FP clinics }\end{array}$ \\
\hline Providers & WT Provide Survey & $\begin{array}{l}\text { FP service providers and members of professional } \\
\text { associations, such as pharmacists, ob/gyns, } \\
\text { midwives, nurses, other providers }\end{array}$ \\
\hline Procurers & WT Procure Survey & $\begin{array}{l}\text { MoH, UNFPA, USAID Mission, and large } \\
\text { pharmaceutical distributors }\end{array}$ \\
\hline
\end{tabular}

a) Price-Tracking Survey: In this survey, adapted from the price-tracking survey manual designed by the World Health Organization (WHO) and Health Action International ( $\mathrm{HAl}),{ }^{9}$ we tracked the real prices paid by women for family planning services/products in the three sectors: public, private nonprofit, and private commercial. This survey consisted of interviews with staff in facilities that were responsible for FP commodities management to get a snapshot of the pricing landscape of contraceptives currently sold in-country and to estimate the "Affordability" of the product and the "Ability to Pay" of potential PVR consumers to enable competitive pricing of the PVR. The respondents included those in charge of selected health facilities, including pharmacies and social-marketing outlets. A total of 62 health facilities were assessed in this survey, 17 from the private nonprofit sector and 45 from the private commercial sector.

\footnotetext{
${ }^{9}$ WHO/HAI: http://www.haiweb.org/medicineprices.
} 
b) WT Pay Survey (Consumer Survey): Consisted of interviews with potential PVR consumers directly to estimate the potential number of women who will pay a given price for the PVR and the characteristics of the individuals who will or will not pay that price. Exit interviews were conducted with women as they left facilities where FP services were offered. Respondents were shown a product sample and provided with a detailed description (use/benefits) of the PVR. Respondent interest was ascertained (by providing an option to rate their interest in the PVR before starting the survey) and uninterested respondents were not interviewed after recording the reason for their lack of interest. Questions focused on PVR pricing following a bidding game model based on the Contingent Valuation methodology as shown in Figure 3 (Foreit and Foreit 2001). Questions started with a modest PVR starter price, which was pegged at US\$1.70 (N300) in all three sectors. ${ }^{10}$ The series of questions assume a $10 \%$ increase in price and subsequently a higher or lower increase based on the participant's response. We ended the interview with two open-ended questions: (1) We asked about the maximum price the participant was willing to pay for the PVR independent of the previously mentioned prices; and (2) We sought to know the possible action the respondent would take if the price was found to be too high. Survey respondents included 400 urban and peri-urban women aged 18 and above seeking family planning services at selected health facilities in Abuja. The number was distributed as follows: public (229); private nonprofit (80), and private commercial (91), following a stratified sampling strategy.

c) WT Provide Survey: For providers, a "WT Provide Survey" was conducted. Family planning service providers in selected health facilities were aged 18 years and above. We interviewed a total of 50 providers-public (14), private nonprofit (3), and private commercial (33) sectors. The providers were asked qualitative questions to gauge their willingness to provide the PVR as part of the existing FP method mix in their health facilities. In addition, they were asked to estimate the maximum amount that should be charged (if any) for providing the PVR. Respondents included randomly selected FP providers such as gynecologists, nurses and matrons, pharmacists, and community health workers.

d) WT Procure Survey: For the procurers, a "WT Procure Survey" was conducted and included representatives of government, and of social marketing and donor agencies involved in procuring FP commodities. A total of 19 procurers were interviewed. Procurers were asked to provide the price list of procured FP commodities and their assessment of a reasonable price estimate for procuring the PVR, to assess their willingness to procure it.

10 US\$1.70 (N300) is the mean price of 3-month injectable contraceptives in Nigeria; there are marginal variations in price within the private sector (nonprofit versus commercial). FP commodities in the public sector are free, but we still used the starter price to determine WTP as this would serve as a realistic starter price for a public-sector client if the product were not available in the public sector. 
FIGURE 2 CONSUMER SURVEY: BIDDING-GAME MODEL

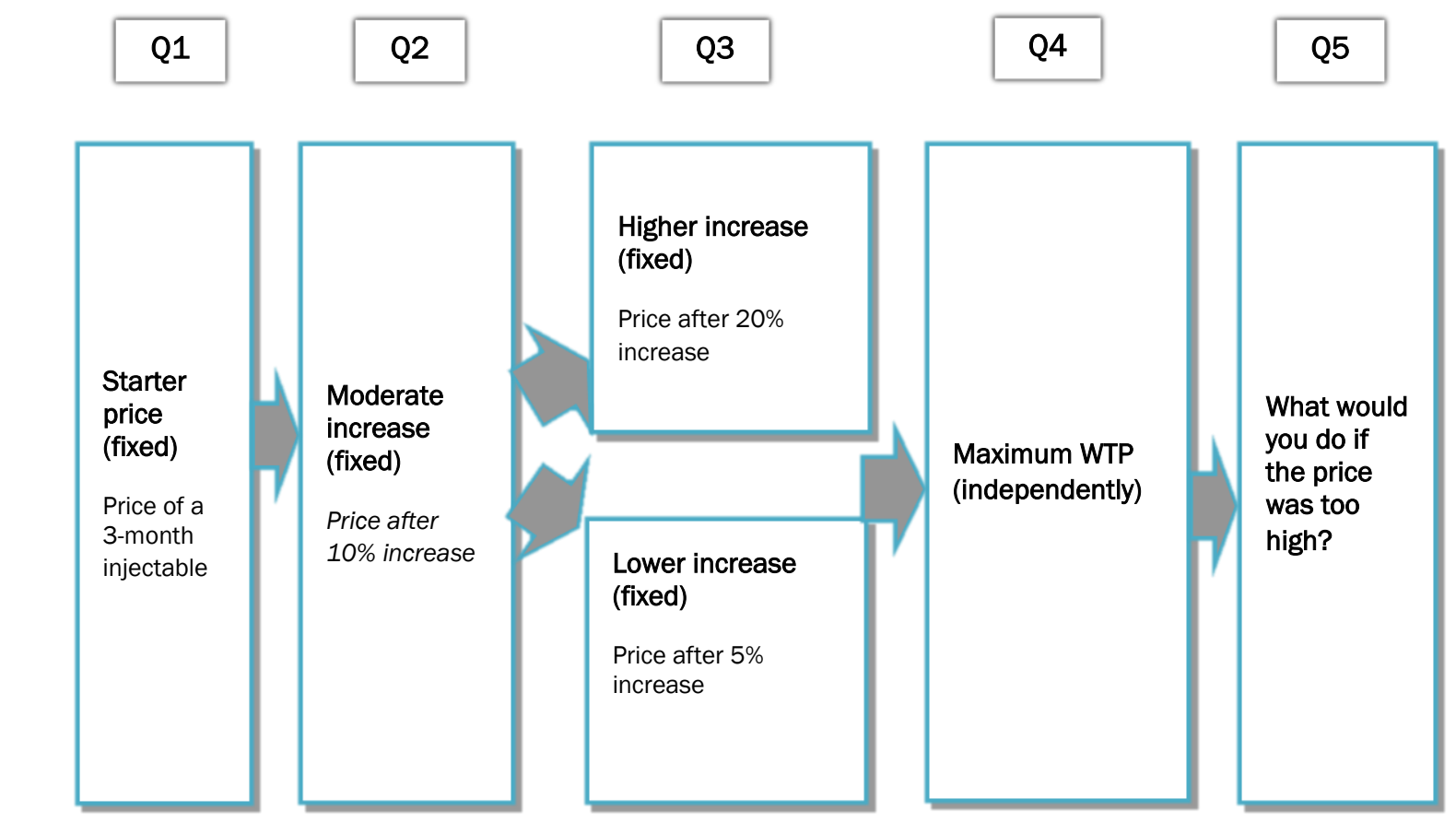

Source: Foreit and Foreit. 2001. "Willingness to pay surveys for setting prices for reproductive health products and services: A user's manual." Frontiers in Reproductive Health, Population council, Policy Project, and Futures Group International.

\section{IMPLEMENTATION}

Ethics clearance: The Federal Capital Territory Health Research Ethics Committee (FCTHREC) granted ethical clearance for the study. Informed consent was obtained from all participants. Anonymity of participants and confidentiality of the information provided was ensured.

Site selection: The Federal Capital Territory (FCT) of Abuja, Nigeria's capital city, was selected for the surveys because it provides a fair representation of the key population groups. Public family-planning centers and service-delivery facilities run by nonprofit organizations within and around the federal capital were also selected. Last, private commercial facilities were selected based on the availability of skilled providers and clients' volume at those facilities.

Training of data collectors: Training followed a systematic process that ensured data collectors' effectiveness during the actual fieldwork. In the first phase of this process, a cascaded training model was used to train data collectors on the survey process, data-collection instruments, and the ethical conduct of the study. Survey tools were pretested and suggested modifications were incorporated prior to study implementation. All the data collectors participating in the study had previous experience conducting surveys in this setting. 


\title{
Results
}

\section{PRICE-TRACKING SURVEY}

\author{
Intersectoral Price Comparisons
}

Table 3 shows the median prices of various contraceptives in the private nonprofit versus private commercial sectors. Tracking prices across these sectors provides useful information for tailoring affordable pricing strategies for the PVR given its utility and comparative advantages. As FP commodities are free in Nigeria's public facilities, this sector was not tracked. As shown in Table 3, injectable contraceptives (which are progestinonly and administered every three months like the PVR) are sold at the median prices of US $\$ 2.70$ (N438) and

TABLE 3 Median prices of commonly available contraceptives by sector ${ }^{11}$

\begin{tabular}{lcc}
\hline Contraceptive & $\begin{array}{c}\text { Private Nonprofit } \\
\text { Sector (Naira) }\end{array}$ & $\begin{array}{c}\text { Private Commercial } \\
\text { Sector (Naira) }\end{array}$ \\
\hline Injectables & 200 & 438 \\
Male Condoms & 188 & 315 \\
Female Condoms & 300 & - \\
Combined Pills & 300 & 100 \\
EC Pills & 300 & 4,300 \\
Implanon (1 rod) & 200 & 3,000 \\
Jadelle (2 rods) & - & 3,000 \\
Copper IUD & 450 & 2,000 \\
LNG-IUS (Mirena ${ }^{\circledR}$ ) & 1,000 & - \\
\hline
\end{tabular}

$-=$ Price not available.

(US\$1.30) N200 in the private commercial and private nonprofit sectors, respectively. EC pills have the highest median price of approximately US $\$ 27(\mathrm{~N} 4,300)$ in the private commercial sector, which may indicate how much women are willing to spend to prevent unintended pregnancies. The Levonorgestrel Intrauterine System (LNG-IUS) is typically very expensive (ranging from N1,000N8,000 or US $\$ 6-\$ 50$ if found in private clinics), but is mostly offered free of charge in private nonprofit outlets (with a minimal service fee of N1,000) through a donation from the International Contraceptive Access Foundation (ICAF). In general, median prices for contraceptive commodities are higher in the private commercial sector than the nonprofit sector, as should be expected.

\section{Method Availability by Sector}

A wide variety of contraceptives are available in the three sectors; injectables and pills are the most popular among consumers, next to male condoms. Across the three sectors, the injectable Noristerat and the emergency contraceptive pill Postinor 2 are the most popular brands. Other commonly available brands include Gold Circle (male condoms), Depo Provera (injectable), Copper T (IUD), Jadelle (implant), and combined oral contraceptives. Respondents indicated that stocks are replenished on a monthly basis for the most popular methods in their facilities.

11 At the time of the survey, US\$1 = N160. 


\section{CONSUMER SURVEY}

\section{Sector Demographics}

As depicted in Table 4, of the 400 consumers surveyed, 229, 80, and 91 were from the public, private nonprofit, and private commercial sectors, respectively. In all the sectors, the majority of respondents fell between the ages of 25 and 39 corresponding to the ages for peak fertility in Nigeria. Similarly, over $80 \%$ of the surveyed consumers completed secondary or college education, indicating a highly educated population of women. In this sample, the proportion of respondents who had no education was low whether they were in the public $(0.9 \%)$ or private nonprofit $(1.3 \%)$ sectors. The majority of the respondents have $1-3$ children with $61 \%, 51 \%$, and $58 \%$ of women from the public, private nonprofit, and private commercial sectors, respectively, falling in this category. About $20 \%$ of respondents across the three sectors have no children, and $1.7 \%$ of women have more than 5 children as compared to the total fertility rate (TFR) of 5.5 in the country (NPC and ICF International 2014). Overall, the consumers who participated in this study are representative of the urban rich profile, with higher social status and presumably higher levels of ability to pay.

TABLE 4 Sociodemographic characteristics of study participants by sector

\begin{tabular}{|c|c|c|c|c|c|c|}
\hline \multirow[t]{2}{*}{ Variable } & \multicolumn{2}{|c|}{ Public Sector } & \multicolumn{2}{|c|}{ Private Nonprofit Sector } & \multicolumn{2}{|c|}{ Private Commercial Sector } \\
\hline & $\mathrm{N}=229$ & $\%$ & $\mathrm{~N}=80$ & $\%$ & $\mathrm{~N}=91$ & $\%$ \\
\hline \multicolumn{7}{|l|}{ Age } \\
\hline $15-19$ & 6 & 3 & 0 & 0 & 1 & 1 \\
\hline $20-24$ & 31 & 14 & 3 & 4 & 9 & 10 \\
\hline $25-29$ & 67 & 29 & 27 & 34 & 27 & 30 \\
\hline $30-34$ & 54 & 24 & 25 & 31 & 25 & 28 \\
\hline$>35$ & 71 & 31 & 23 & 28 & 27 & 29 \\
\hline \multicolumn{7}{|l|}{ Education } \\
\hline Primary & 19 & 8 & 3 & 4 & 5 & 27 \\
\hline Secondary & 94 & 41 & 20 & 25 & 24 & 26 \\
\hline College & 93 & 41 & 47 & 59 & 51 & 56 \\
\hline None & 2 & 1 & 1 & 1 & 0 & 0 \\
\hline \multicolumn{7}{|l|}{ Number of children } \\
\hline None & 33 & 14 & 20 & 25 & 23 & 25 \\
\hline $1-3$ & 139 & 61 & 41 & 51 & 53 & 58 \\
\hline $4-5$ & 48 & 21 & 10 & 13 & 13 & 14 \\
\hline$>5$ & 6 & 3 & 1 & 1 & 1 & 1 \\
\hline \multicolumn{7}{|l|}{ Marital status } \\
\hline Yes & 213 & 93 & 68 & 85 & 76 & 84 \\
\hline No & 15 & 7 & 11 & 14 & 15 & 17 \\
\hline \multicolumn{7}{|l|}{ FP use/intent } \\
\hline Yes, currently use & 83 & 36 & 21 & 26 & 25 & 28 \\
\hline Yes, intend to use in future & 146 & 64 & 55 & 69 & 66 & 73 \\
\hline
\end{tabular}

Almost all of the respondents were either currently using a contraceptive method or intended to use one in the future. This may in part reflect the study design and the future contraceptive demand in the country, at least for women in urban and peri-urban settings where this study took place. 
Socioeconomic Characteristics of Study Participants by Sector

TABLE 5 Socioeconomic characteristics of study participants by sector

\begin{tabular}{|c|c|c|c|c|c|c|}
\hline \multirow[t]{2}{*}{ Variable } & \multicolumn{2}{|c|}{ Public Sector } & \multicolumn{2}{|c|}{ Private Nonprofit Sector } & \multicolumn{2}{|c|}{ Private Commercial Sector } \\
\hline & $n=229$ & $\%$ & $n=80$ & $\%$ & $n=91$ & $\%$ \\
\hline \multicolumn{7}{|l|}{ Occupation } \\
\hline Housewife/not working & 48 & 21 & 15 & 19 & 11 & 12 \\
\hline Retail & 31 & 14 & 11 & 14 & 15 & 17 \\
\hline Wholesale trade & 17 & 7 & 1 & 1 & 4 & 4 \\
\hline Agriculture/livestock & 2 & 1 & 0 & 0 & 2 & 2 \\
\hline Private work & 27 & 12 & 31 & 39 & 42 & 46 \\
\hline Government work & 69 & 30 & 9 & 11 & 9 & 10 \\
\hline Manual work & 17 & 7 & 6 & 8 & 2 & 2 \\
\hline \multicolumn{7}{|l|}{ Partner's Occupation } \\
\hline Not working & 2 & 1 & 0 & 0 & 1 & 1 \\
\hline Retail & 5 & 2 & 1 & 1 & 1 & 1 \\
\hline Wholesale trade & 9 & 4 & 1 & 1 & 10 & 11 \\
\hline Agriculture/livestock & 4 & 2 & 1 & 1 & 3 & 3 \\
\hline Private work & 63 & 28 & 28 & 35 & 28 & 31 \\
\hline Government work & 74 & 32 & 22 & 28 & 17 & 19 \\
\hline Manual work & 28 & 12 & 6 & 8 & 5 & 6 \\
\hline \multicolumn{7}{|l|}{ Household Items } \\
\hline Television & 215 & 94 & 79 & 99 & 89 & 98 \\
\hline Refrigerator & 169 & 74 & 70 & 88 & 74 & 81 \\
\hline Vehicle & 115 & 50 & 45 & 56 & 39 & 43 \\
\hline Mobile & 221 & 97 & 80 & 100 & 87 & 96 \\
\hline Radio & 195 & 85 & 70 & 88 & 80 & 88 \\
\hline \multicolumn{7}{|l|}{ Salon Visits } \\
\hline Weekly & 53 & 23 & 17 & 21 & 15 & 17 \\
\hline Two weeks/biweekly & 35 & 15 & 16 & 20 & 12 & 13 \\
\hline Monthly & 103 & 45 & 38 & 48 & 49 & 54 \\
\hline Does not visit & 29 & 13 & 7 & 9 & 8 & 9 \\
\hline \multicolumn{7}{|l|}{ Monthly Income (Naira) } \\
\hline $1,000-10,000$ & 15 & 7 & 1 & 1 & 4 & 4 \\
\hline $10,001-50,000$ & 69 & 30 & 20 & 25 & 30 & 33 \\
\hline$>50,000$ & 69 & 30 & 29 & 36 & 29 & 32 \\
\hline No response/Does not know & 76 & 33 & 30 & 38 & 28 & 31 \\
\hline \multicolumn{7}{|l|}{ Monthly Expenses (Naira) } \\
\hline $1,000-10,000$ & 24 & 11 & 1 & 1 & 9 & 10 \\
\hline$>10,000-50,000$ & 95 & 42 & 29 & 36 & 31 & 34 \\
\hline$>50,000$ & 60 & 27 & 24 & 31 & 26 & 29 \\
\hline No response/Does not know & 50 & 22 & 26 & 33 & 25 & 28 \\
\hline \multicolumn{7}{|l|}{ Monthly FP Expense (Naira) } \\
\hline $1,000-10,000$ & 9 & 4 & 1 & 1 & 2 & 2 \\
\hline$>10,000-50,000$ & 28 & 13 & 10 & 13 & 12 & 13 \\
\hline$>50,000$ & 7 & 7 & 4 & 4 & 6 & 6 \\
\hline No response/Does not know & 185 & 81 & 66 & 83 & 71 & 78 \\
\hline
\end{tabular}


Table 5 depicts the socioeconomic characteristics of the respondents. More than $80 \%$ of the consumers surveyed were gainfully employed. This nearly mirrors the Nigeria Demographic and Health Survey 2013, which indicates that more than $70 \%$ of Nigerian women were employed, with 7 out of 10 of the employed women able to make independent decisions on how they spend their earnings. The majority of the women reported household monthly incomes of between N10,000 (US\$63) and N100,000 (US\$625), with about 16\% reporting more than N100,000 per month.

More than half of the women (59\%) across the three sectors visit a hair salon on a monthly basis, whereas $20 \%$ visit on a weekly basis. Although most of the respondents did not disclose their monthly expenditure for family planning services, the high employment rate and the average monthly income of the respondents suggest a population with high purchasing power, increasing the potential for consumers to purchase the PVR. Across the three sectors, $13 \%$ of respondents indicated that they spent between $\mathrm{N} 10,000$ (approximately US $\$ 63$ ) and N50,000 (approximately US $\$ 313$ ) on their family planning needs. The frequency of hair salon visits among consumers in this study suggests the availability of discretionary income; however, the extent to which decisions on discretionary expenses are made will depend on the range of needs that women may have and the priority they give to reproductive health and FP services.

\section{WTP for the PVR by Level of Increments and Sector}

Table 6 shows that over 95\% of respondents were interested in the PVR and participated in the bidding game. Consumers responded to hypothetical increases in the price of the PVR starting from a fixed price of N300 (approximately US\$2), which is the median cost of injectable contraceptives that are also administered every three months. More than $89 \%$ of respondents surveyed in the public sector (195), $90 \%$ in the private nonprofit sector (70), and $94 \%$ in the private commercial sector (85) were willing to buy the PVR at the starting price. This shows that most women who use all the sectors are willing to purchase the commodity at a price comparable to the cost of injectable contraceptives, with increasing tendency to do so moving from the public to private commercial sector. The same pattern of higher willingness to pay in the private compared to the public sector continues with increases in the price of the PVR by $10 \%$ and $20 \%$. For example, when the starter price was increased by $20 \%$, although there was a decline in the willingness to pay across all the three sectors, those in the private nonprofit (74\%) and private commercial (83\%) sectors were more willing to purchase the PVR than those in the public sector (71\%).

TABLE 6 WTP for the PVR by level of increments and sector

\begin{tabular}{|c|c|c|c|c|c|c|}
\hline \multirow[t]{2}{*}{ Variable } & \multicolumn{2}{|c|}{ Public Sector $(n=229)$} & \multicolumn{2}{|c|}{$\begin{array}{l}\text { Private Nonprofit Sector } \\
\qquad(n=80)\end{array}$} & \multicolumn{2}{|c|}{$\begin{array}{l}\text { Private Commercial Sector } \\
\qquad(n=91)\end{array}$} \\
\hline & & $\%$ & & $\%$ & & $\%$ \\
\hline Respondents interested in PVR & 218 & 95 & 78 & 98 & 90 & 99 \\
\hline Starter price & 195 & 89 & 70 & 90 & 85 & 94 \\
\hline $10 \%$ increment & 170 & 78 & 64 & 82 & 80 & 89 \\
\hline $20 \%$ increment & 154 & 71 & 58 & 74 & 75 & 83 \\
\hline
\end{tabular}

For the PVR, over $85 \%$ of respondents interested in the method across the board indicated that they will pay an additional $5 \%$ over their maximum WTP amount if it would help widen FP access to women in low-resource settings. This altruistic willingness to pay is over $93 \%$ among respondents who access the private commercial sector for contraceptive services (as shown in Table 7). 
TABLE 7 Altruistic WTP for the PVR by sector

\begin{tabular}{lcccccc}
\hline $\begin{array}{l}\text { Altruistic WTP (WTP 5\% over } \\
\text { maximum stated amount if } \\
\text { used to help other women) }\end{array}$ & Public Sector & Private Nonprofit Sector & $\begin{array}{c}\text { Private Commercial } \\
\text { Sector }\end{array}$ \\
\hline & $\mathrm{n}=229$ & $\%$ & $\mathrm{n}=80$ & $\%$ & $\mathrm{n}=91$ & $\%$ \\
\hline Yes & 195 & 85 & 70 & 87 & 85 & 93 \\
No & 31 & 14 & 10 & 13 & 6 & 7 \\
Does not know & 3 & 1 & 0 & 0 & 0 & 0 \\
\hline
\end{tabular}

\section{Sector Demand Curve}

Figure 3 shows the PVR demand curve from the public sector consumers. In this sector, the willingness to pay for the PVR is plotted against a range of incremental hypothetical prices in order to gauge the value consumers place on the ring. It is clear that the demand falls with increasing pricethere is a considerable decline in WTP from N200 or US $\$ 1(76 \%)$ to N300 or US\$2 (31\%) and it continues to fall until $\mathrm{N} 600$ or US $\$ 4$ at which only $5 \%$ of the women were willing to pay for the ring. However, it is important to note that contraceptive commodities are free of charge in the public health system across Nigeria and this category of consumers are accustomed to receiving commodities free of charge. Given this knowledge, we can conservatively assert that consumers within the public sector place high value on the ring, as up to $76 \%$ of them would still have a demand for the ring at a price of $\mathrm{N} 200$ (US\$1) which is equivalent to the price of a pound of onions in Abuja.

\section{FIGURE 3 CONSUMER DEMAND CURVE FOR PVR-PUBLIC SECTOR}

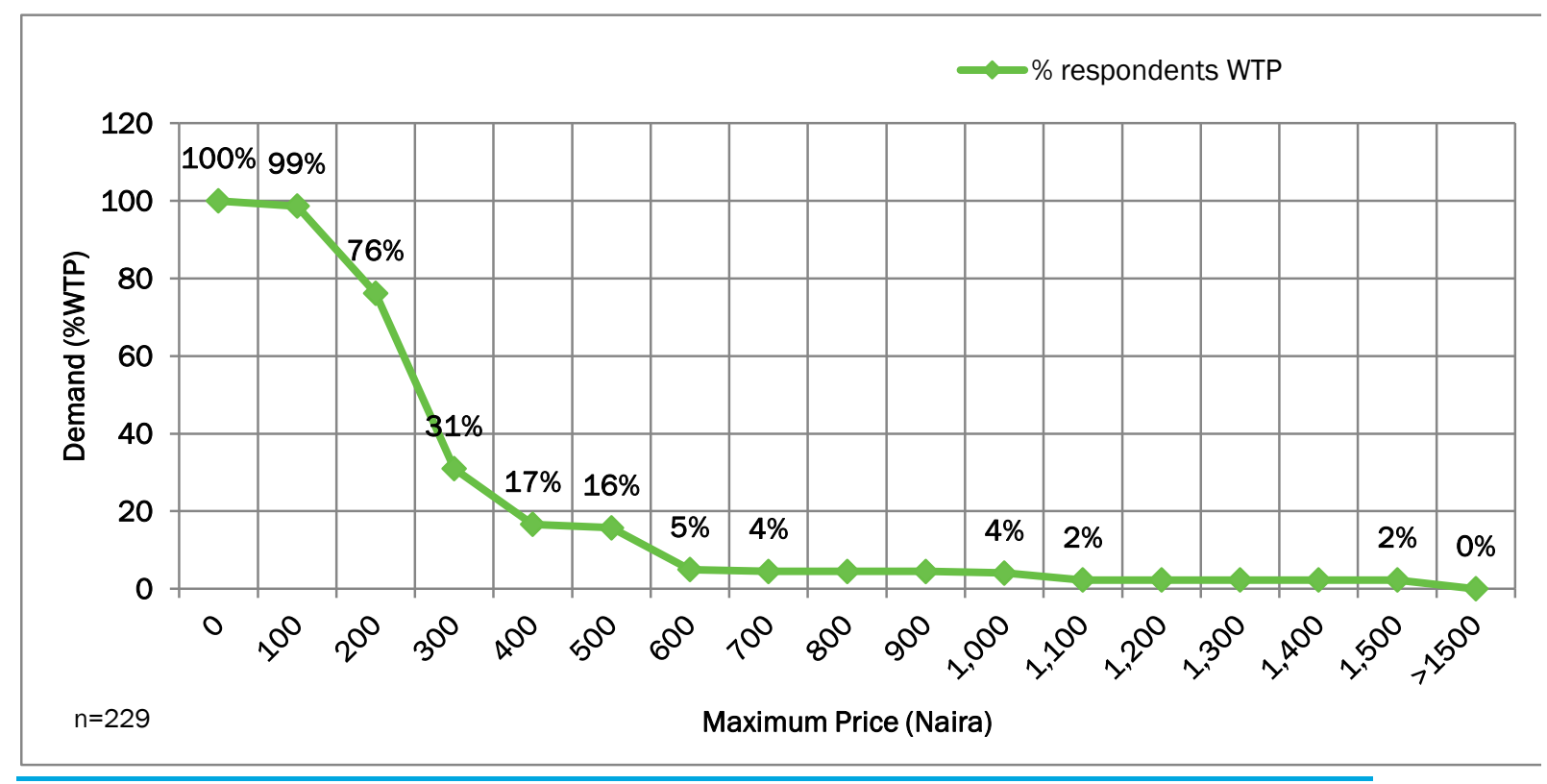


In contrast, the demand curve for consumers who obtain services through the private nonprofit sector showed different demand outcomes, as depicted in Figure 4. In this case, at a price of N200, the demand for the PVR is still high at $90 \%$. Thereafter, there is a sharp decline in the demand curve, with $32 \%$ willing to pay for the ring at N500 (US\$3). The demand curve for consumers who obtain their services from the private commercial sector is similar; demand for the PVR is at $93 \%$ when the price of the PVR is at N200 and declines thereafter (as shown in Figure 5).

\section{FIGURE 4 CONSUMER DEMAND CURVE FOR PVR-PRIVATE NONPROFIT SECTOR}

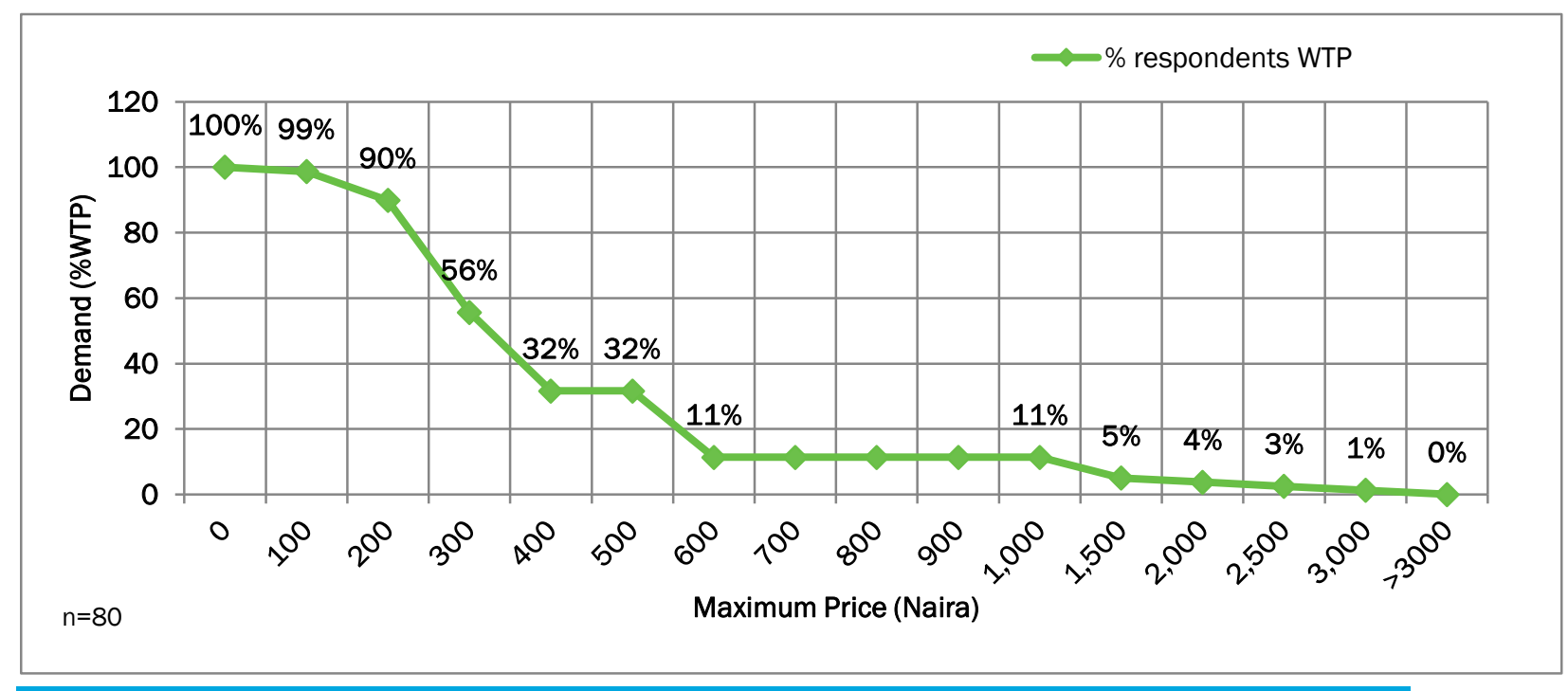

The inflection point in the demand curve occurs around the $\mathrm{N} 600$ for the private sectors, although there is robust demand at prices above that as well. For the public sector, the inflection point is at prices close to approximately N500.

\section{FIGURE 5 CONSUMER DEMAND CURVE FOR PVR-PRIVATE COMMERICAL SECTOR}

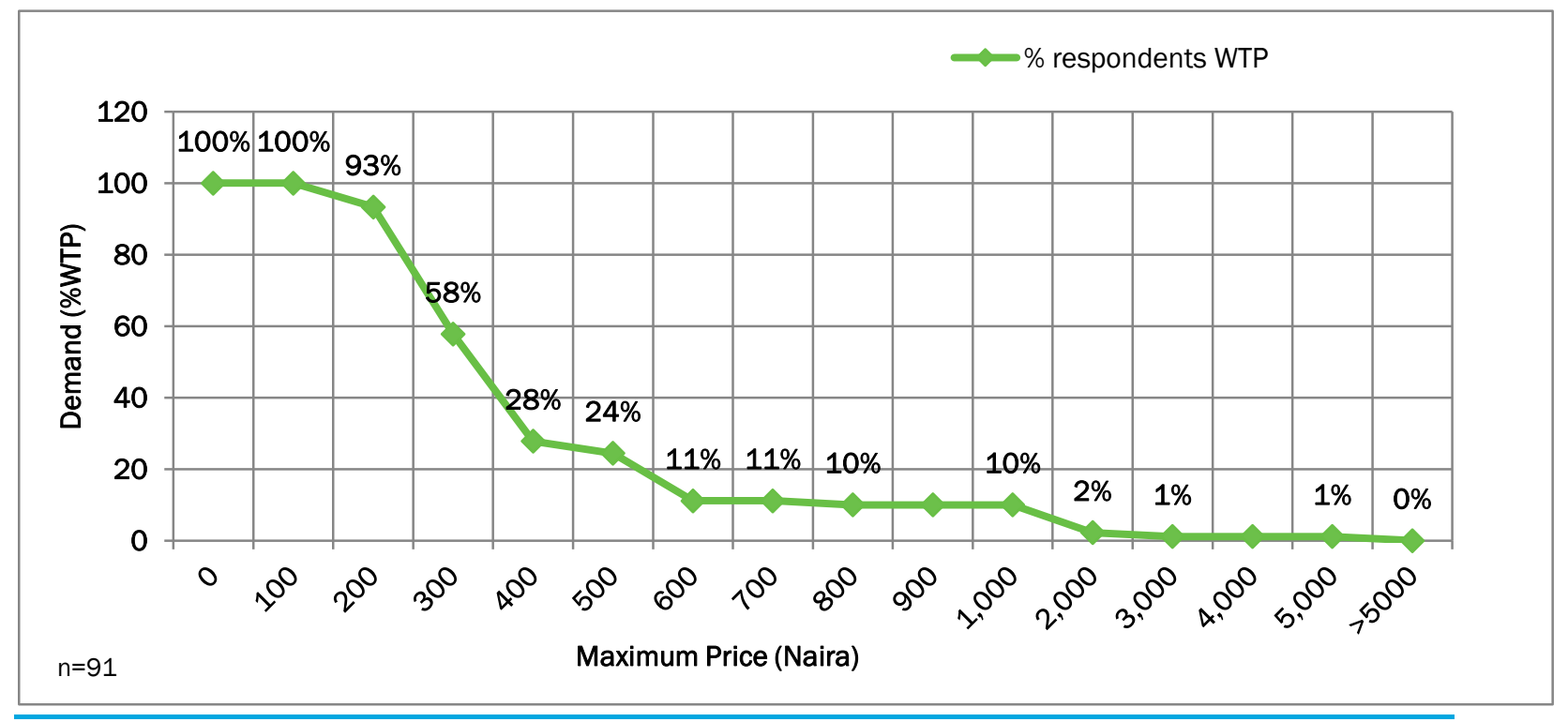


In addition to analyzing the economic aspects of decision-making, we also examined other reasons why consumers would be willing to pay for the ring. Figure 6 displays the relative contributions of other determinants of demand across the public, private nonprofit, and private commercial sectors, respectively. As the figure depicts, the price of the ring is a very important consideration for consumers across all sectors, but the relative contribution of price progressively diminishes from the public to the private sector. For example, while $54 \%$ of public sector consumers would purchase the ring because the price is perceived to be affordable, fewer consumers in the private nonprofit (36\%) and private commercial (37\%) sectors, respectively, would make purchase decisions based on the price.

The next important consideration in women's demand for the ring is fear of the economic consequences of unintended pregnancy, leading to higher expenses. The relative value of this determinant varies from sector to sector. Fear of unintended pregnancy as a determinant of demand is highest among consumers in the private nonprofit sector (31\%), followed by the private commercial sector (27\%), and last, the public sector (24\%).

FIGURE 6 REASONS FOR WTP FOR THE PVR BY SECTOR

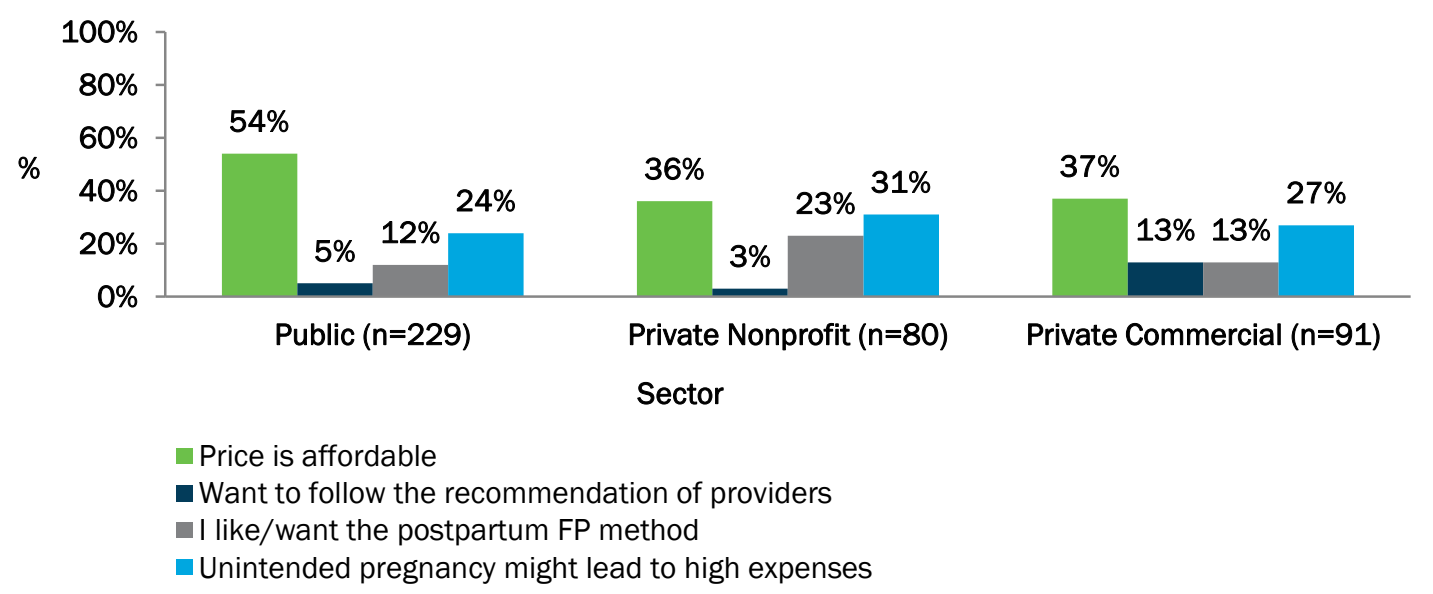

The next most important determinant as reported by consumers is the desire for an effective family planning method during the postpartum period, with $23 \%, 13 \%$, and $12 \%$ of private nonprofit, private commercial, and public sector consumers, respectively, willing to pay for the ring on this account. (See Figure 6.) Other reasons include recommendations of health service providers and other nonspecific considerations. What this implies is that women, irrespective of where they receive their contraceptive services, are not motivated only by one factor such as the price of the method alone. The motivation for demand for a given product/service varies from one woman to another depending on the prevailing socioeconomic circumstances, but the price is an important general consideration. 
TABLE 8 WTP for the one-year CVR by level of increments and sector

\begin{tabular}{|c|c|c|c|c|c|c|}
\hline \multirow[t]{2}{*}{ Variable } & \multicolumn{2}{|c|}{ Public Sector } & \multicolumn{2}{|c|}{ Private Nonprofit Sector } & \multicolumn{2}{|c|}{ Private Commercial Sector } \\
\hline & $n=229$ & $\%$ & $\mathrm{n}=80$ & $\%$ & $n=91$ & $\%$ \\
\hline Starter price & 145 & 65 & 60 & 77 & 66 & 75 \\
\hline $10 \%$ increment & 119 & 54 & 52 & 67 & 55 & 63 \\
\hline $20 \%$ increment & 98 & 45 & 43 & 55 & 48 & 55 \\
\hline Respondents interested in PVR & 219 & 96 & 78 & 98 & 88 & 97 \\
\hline
\end{tabular}

As the Council introduces the PVR in Nigeria, the experience and lessons learned from this process will be utilized to guide similar introductory efforts for another ring type, a long-acting combined hormonal vaginal ring developed for contraceptive protection outside the breastfeeding period. As shown in Table 8, over 95\% of respondents, irrespective of sector, were interested in this ring. In the bidding game for this ring, consumers in the public (65\%), private nonprofit (77\%), and private commercial (75\%) sectors expressed willingness to pay for this one-year CVR at the starter price. With price increases, although there is a decline in the willingness to pay, the demand is still high; for example, at a $20 \%$ increase over the starter price, $45 \%$ of public sector consumers and $55 \%$ of private sector consumers would still be willing to pay for the product.

\section{FIGURE 7 CONSUMER DEMAND CURVE FOR ONE-YEAR CVR-PUBLIC SECTOR}

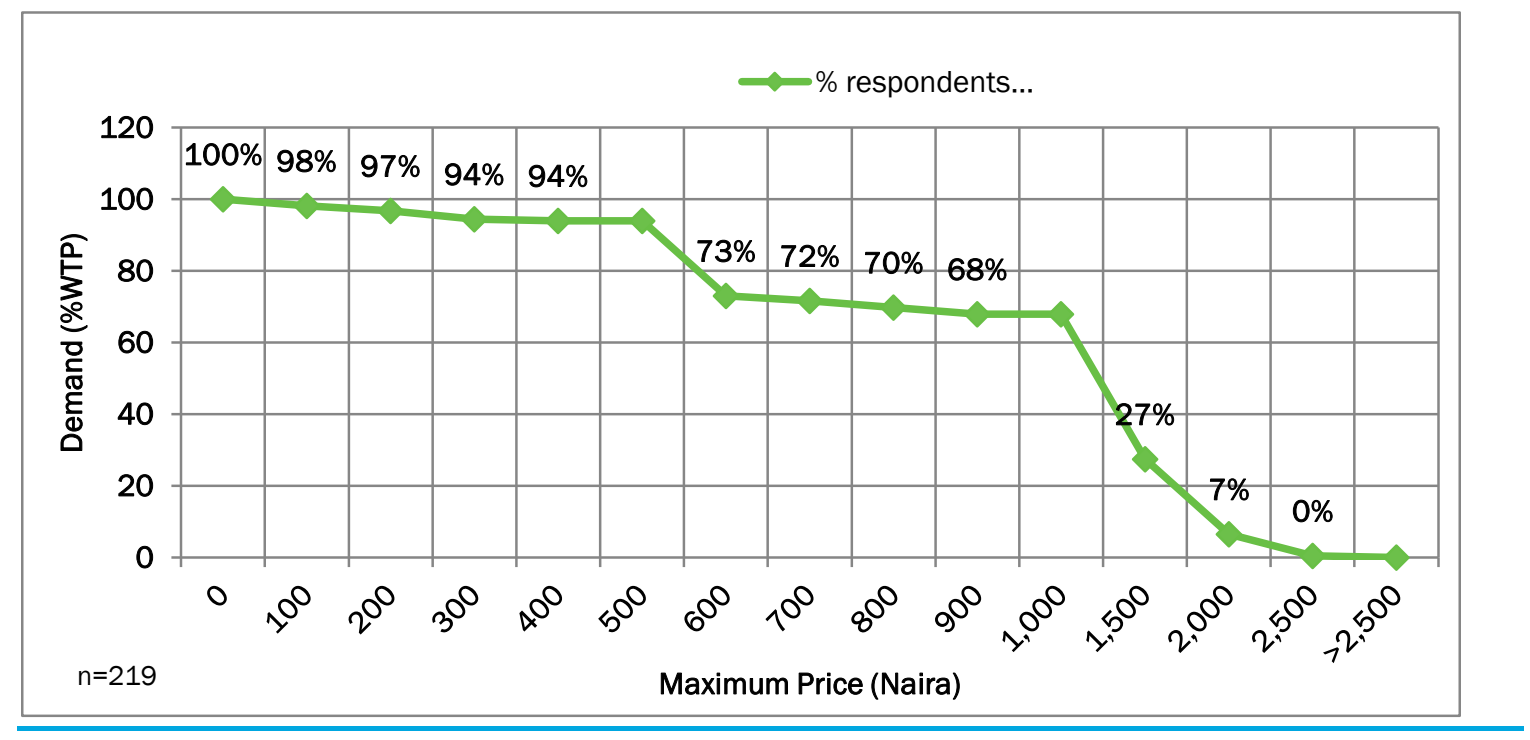

As can be seen in Figure 7, demand for the one-year CVR in the public sector remains high with incremental prices up to N1,000 or US $\$ 6$ (68\%). Even at N1,500 or US $\$ 9,27 \%$ of the consumers expressed willingness to buy the one-year ring. In the private nonprofit sector, the demand stays high at $84 \%$ even at a price of $\mathrm{N} 1,500$ (Figure 8 ), while $81 \%$ of consumers in the private commercial sector would buy the one-year CVR at the same N1,500 (Figure 9). The analysis indicates that N1,000 is the inflection point in the demand curves of all sectors for the investigational one-year CVR. It is clear that consumers are willing to pay for the one-year CVR at much higher prices than they would for the PVR. One reason for this preferential demand for the investigational one-year CVR at a much higher price could be the ring's duration of action, which is one year as opposed to the PVR which lasts for three months. 
FIGURE 8 CONSUMER DEMAND FOR ONE-YEAR CVR-PRIVATE NONPROFIT SECTOR

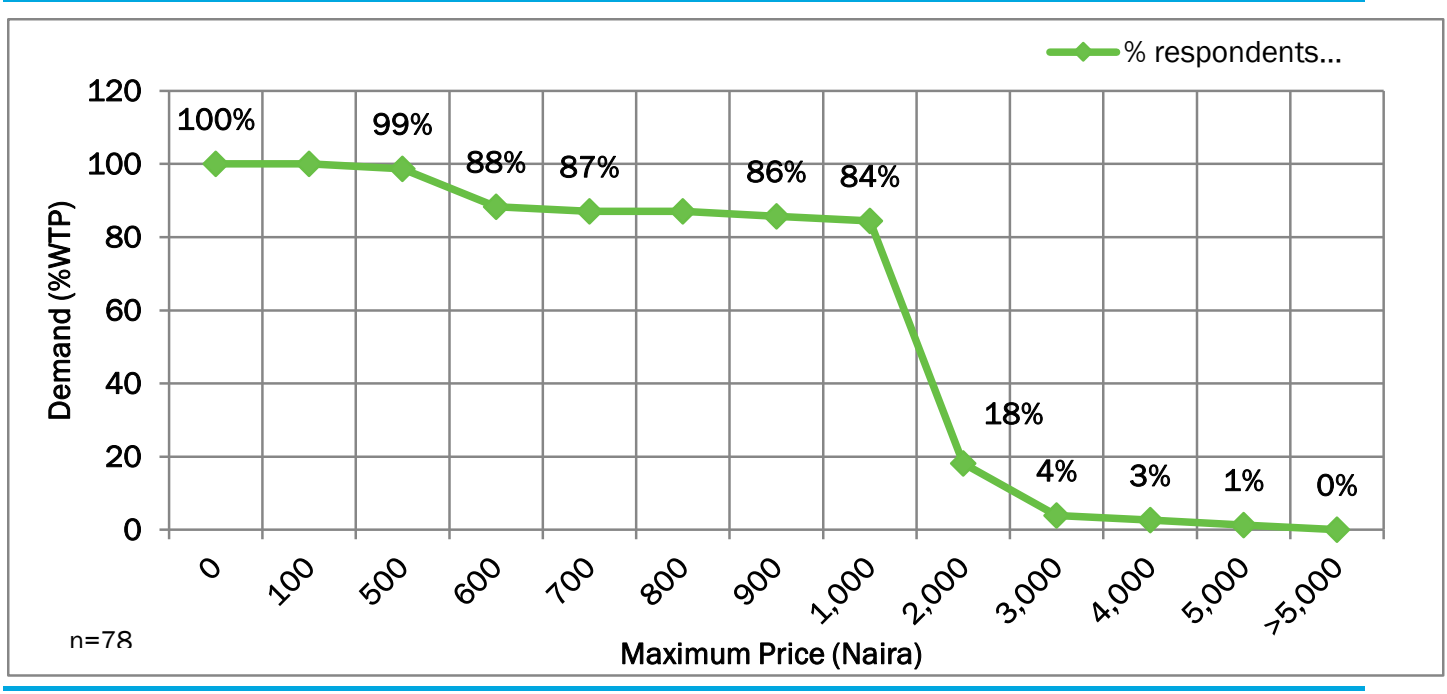

FIGURE 9 CONSUMER DEMAND FOR ONE-YEAR CVR-PRIVATE COMMERCIAL SECTOR

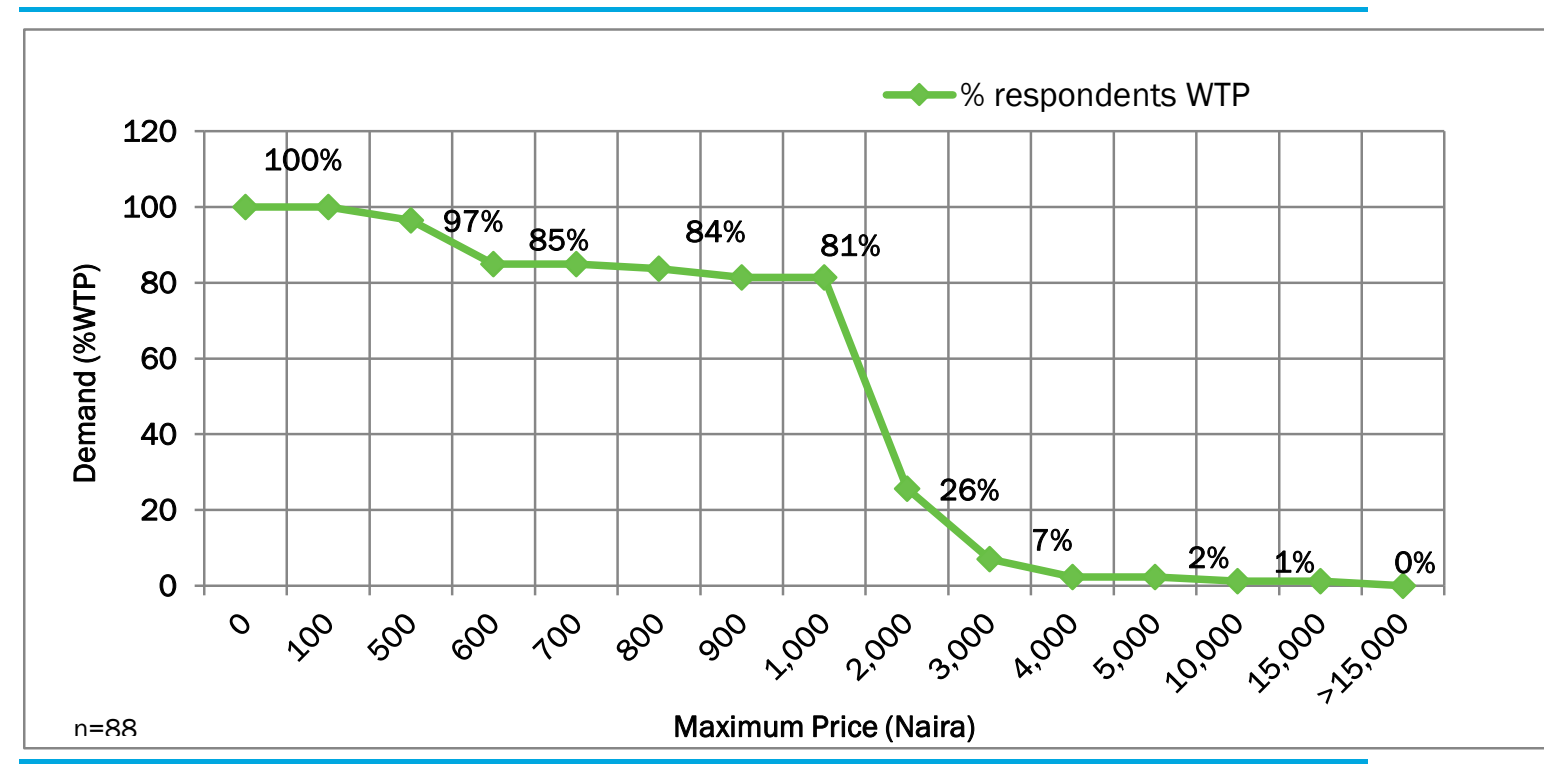

Consumers' perception of the PVR is generally encouraging (Table 9). Many believe it is a good innovation for breastfeeding women who want to use a modern method of contraception for spacing. Many would recommend it to others because they perceive that it has little or no side effects. However, some women feel that the PVR is invasive because of its vaginal use and others feel that the size of the PVR is unappealing. It is to be noted that responses on size and shape are typical when respondents are asked about perceptions without having had any experience using the ring. ${ }^{12}$

12 Women who had used the ring for another study reported that size, color, and texture were not important determinants; with use, responses on all of these three attributes improved over time. 
TABLE 9 Consumer comments on PVR and one-year CVR by sector

\begin{tabular}{|c|c|c|}
\hline Sector & Comments on PVR & Comments on One-Year CVR \\
\hline Public & $\begin{array}{l}\text { "The product is okay/good. It is affordable." } \\
\text { "It is easy to use." } \\
\text { "I am skeptical about the product." } \\
\text { "Maintain the quality of the product." } \\
\text { "Make it good, effective, or improve the quality (size, } \\
\text { packaging, duration)." }\end{array}$ & $\begin{array}{l}\text { "Product is okay. Make it available." } \\
\text { "It is easy to use." } \\
\text { "I like the product. I recommend it to women." } \\
\text { "Prefer other products. Will give it a trial, because } \\
\text { of duration (of use)." }\end{array}$ \\
\hline $\begin{array}{l}\text { Private } \\
\text { Nonprofit }\end{array}$ & $\begin{array}{l}\text { "The product is good." } \\
\text { "Make it affordable." } \\
\text { "Make it available." } \\
\text { "I am willing to buy it." }\end{array}$ & $\begin{array}{l}\text { "Product is okay/good." } \\
\text { "Make it affordable." } \\
\text { "Maintain the quality of the product. I like the } \\
\text { product and will recommend it to women." }\end{array}$ \\
\hline $\begin{array}{l}\text { Private } \\
\text { Commercial }\end{array}$ & $\begin{array}{l}\text { "Make it easy to use and provide assistance for use." } \\
\text { "It is invasive." } \\
\text { "It is safe, with little or no side effects." }\end{array}$ & $\begin{array}{l}\text { "I like the product. I will recommend it to women." } \\
\text { "There is a need to create more awareness } \\
\text { among women." }\end{array}$ \\
\hline
\end{tabular}

\title{
PROVIDER SURVEY
}

\author{
Provider Profile by Sector
}

TABLE 10 Provider profile by sector

\begin{tabular}{l|l}
\hline Sector & \multicolumn{1}{c}{ Profile (Job Titles, Education, Responsibilities Regarding Family Planning) } \\
\hline Public & $\begin{array}{l}\text { Job titles: CHEWs/CHOs; gynecologists; managers; matrons, nurses } \\
\text { Responsibilities regarding FP: Consultation on FP information; counseling and servicing on FP methods; } \\
\text { counseling and guidance; teaching about FP }\end{array}$ \\
\hline Private & $\begin{array}{l}\text { Job title: CHEWs; CHOs; nurses } \\
\text { Education: College } \\
\text { Responsibilities regarding FP: FP Counseling; provide FP commodity to clients }\end{array}$ \\
\hline Private & $\begin{array}{l}\text { Job title: Administrative officers; attendants; auxiliary nurses; CHEWs; laboratory attendants; laboratory } \\
\text { technicians; medical directors, medical officers, managers; matrons, nurses, midwives; pharmacists; } \\
\text { resident doctors; sales representatives } \\
\text { Education: Secondary/College/Graduate } \\
\text { Responsibilities regarding FP: Counseling and dispensing; counseling and treatment; counseling and } \\
\text { administering drugs; selling contraceptive commodities; creating awareness about FP; help clients make the } \\
\text { right method choices; conduct deliveries; provide FP information and services }\end{array}$ \\
\hline
\end{tabular}


A range of providers was interviewed across all sectors. All interviewed providers were involved in some aspect of family planning service delivery, including counseling, commodity provision, education, and administration (Table 10). Providers ranged from gynecologists and obstetricians, to nurses/midwives, Community Health Extension Workers (CHEWs), Community Health Officers (CHOs), and other administrative and supportive staff. Although there are more gynecologists in the public sector than in other sectors, every sector has the necessary mix of skilled personnel to provide the range of methods available in the country.

\section{Sector Qualitative Comments}

TABLE 11 Provider comments on the PVR and one-year CVR by sector

\begin{tabular}{|c|c|c|}
\hline Sector & Comments on PVR & Comments on One-Year CVR \\
\hline Public & $\begin{array}{l}\text { "It is a welcome development." } \\
\text { "It will be easy to use, prevent taking daily pill." } \\
\text { "The price should be subsidized in rural areas." } \\
\text { "The size of the ring is too big." }\end{array}$ & $\begin{array}{l}\text { "I am looking forward to seeing the long-acting } \\
\text { ring." } \\
\text { "This will be good as it is for all women." } \\
\text { "It will replace vaginal cap (not in stock)." }\end{array}$ \\
\hline $\begin{array}{l}\text { Private } \\
\text { Nonprofit }\end{array}$ & $\begin{array}{l}\text { "Good for spacing, if it works as said." } \\
\text { "Training of health workers should be done." }\end{array}$ & "We will like it if there is training." \\
\hline $\begin{array}{l}\text { Private } \\
\text { Commercial }\end{array}$ & $\begin{array}{l}\text { "Reduce the size to make it comfortable." } \\
\text { "I am concerned about its reliability." } \\
\text { "It is good and convenient if tested and proven." } \\
\text { "It is hard and big, may scare the users." } \\
\text { "It will need demonstration for usage." } \\
\text { "It is big to stay at posterior fornix of the vagina." }\end{array}$ & $\begin{array}{l}\text { "I will appreciate it with affordable price." } \\
\text { "It gives opportunity to try new FP method." } \\
\text { "I like the idea of self-administration." } \\
\text { "Its longevity (one year) will be a better idea." } \\
\text { "It will likely interfere with intercourse." }\end{array}$ \\
\hline
\end{tabular}

As was the case with clients' perceptions, providers also expressed feelings about the PVR and the one-year CVR (Table 11). While the majority of comments on the rings were positive, some expressed reservations. For example, while many providers felt that self-use and easy reversibility of the method were positive features, they also reported concerns about the "big size" and the ring's potential for interfering with intercourse. As found in other studies, most of these negative perceptions would likely fade away after the rings are introduced and used. However, as first impression matters, education and support for family planning providers is essential during the introductory phase. Suffice to say that vaginal rings should be introduced in phases, starting with providers at urban and peri-urban public facilities, and gradually scaling up to the urban private sector. 


\title{
PROCURER SURVEY
}

\author{
Procurer Profile by Sector
}

TABLE 12 Provider profile by sector

\begin{tabular}{|c|c|}
\hline Sector & Profile (Job Titles, Responsibilities, Names of Organizations, Products Procured) \\
\hline Public & $\begin{array}{l}\text { Job titles: Chief pharmacist; chief regulatory officer; clinician; director of pharmaceutical services; logistics } \\
\text { officer; logistics manager } \\
\text { Responsibilities regarding FP: Daily stock-taking of RH commodities and ensuring that commodities are } \\
\text { available; logistic officer in charge of procurement and management; provision of FP services to clients; } \\
\text { regulation and registration of FP devices; stock management and reporting and distribution to states; } \\
\text { supervising and coordinating product regulation at NAFDAC } \\
\text { Name of organizations: National Essential Drugs programs; Catholic Relief Services; FMoH; NAFDAC; } \\
\text { National Hospital Abuja } \\
\text { Products procured: Male condoms; IUDs; combined oral contraceptives; implants; EC pills; CycleBeads }\end{array}$ \\
\hline $\begin{array}{l}\text { Private Non- } \\
\text { Profit }\end{array}$ & $\begin{array}{l}\text { Job titles: Nursing officers/midwives, assistant managers, clinical director; clinical service manager; country } \\
\text { director DKT; director of procurement; enterprise fund manager; logistics advisor; logistics and commodity } \\
\text { program manager; national coordinator, CiSFP; program officer for service delivery; program officer for } \\
\text { advocacy; state coordinator, CiSFP; RH coordinator, CRS; national program specialist, FP } \\
\text { Responsibilities regarding FP: Advising the government and providing technical support for quantification; } \\
\text { coordinating FP services for the states; distributing LNG-IUS to FP service facilities; quality assurance and } \\
\text { monitoring; FP needs identification and requisition for communities; advocating for FP interventions with } \\
\text { local and international organizations; marketing and distribution of contraceptive products; social marketing } \\
\text { for FP commodities; stock management and requisition; supporting quantification and supply-chain } \\
\text { procedures for the government; galvanizing actions with civil society organizations to support FP } \\
\text { Name of organizations: CiSFP; CRS; DKT International; FHI 360; JSI; Marie Stopes-Nigeria; MSI; PPFA; } \\
\text { Rotary Club; SFH; UNFPA; USAID } \\
\text { Products procured: Female condoms; implants; LNG-IUS; male condoms; EC pills; implants; injectables; } \\
\text { combined oral contraceptives; IUDs; Sayana Press; CycleBeads }\end{array}$ \\
\hline $\begin{array}{l}\text { Private } \\
\text { Commercial }\end{array}$ & $\begin{array}{l}\text { Job titles: Pharmacist; pharmacy manager; supplementary pharmacist } \\
\text { Responsibilities regarding FP: Dispensing and referring couples for FP services; introducing available FP } \\
\text { methods to clients and counseling on method-administration processes } \\
\text { Name of organizations: Anijah Pharmacy; Bez Pharmacy and Stores Nigeria; Indumex Pharmacy; Rabina } \\
\text { Pharmacy } \\
\text { Product procured: Condoms; EC pills; injectables; combined oral contraceptives }\end{array}$ \\
\hline
\end{tabular}

A wide range of procurers were interviewed including policymakers, regulators, representatives of local and international nongovernmental organizations, community stakeholders, social franchising organizations, civil societies, local and international donors, and representatives of government agencies. Across both the public and private sector, all registered contraceptive commodities in Nigeria are being procured and distributed (Table 12). 


\section{Procurer Priorities (Process, Quality Control, Logistics) by Sector}

TABLE 13 Procurer priorities by sector

\begin{tabular}{|c|c|c|c|}
\hline Domain & Public Sector & Private Nonprofit Sector & Private Commercial Sector \\
\hline $\begin{array}{l}\text { Procurement } \\
\text { Process }\end{array}$ & $\begin{array}{l}\text { "My boss does the } \\
\text { quantification, forecasting, and } \\
\text { planning before mandating to } \\
\text { UNFPA who procures the } \\
\text { commodities. Procurement is } \\
\text { made by direct purchase from } \\
\text { the manufacturers." }\end{array}$ & $\begin{array}{l}\text { "We used a form supplied from } \\
\text { London to enable us do forecasting } \\
\text { based on usage rate." } \\
\text { "We also use 'basket fund' for } \\
\text { procurement, which is donor- } \\
\text { contributed." } \\
\text { "JSI supports, coordinates, } \\
\text { requests from state offices, and } \\
\text { places order (for procurement) } \\
\text { from the manufacturers, while DKT } \\
\text { International procures directly from } \\
\text { the manufacturers." }\end{array}$ & $\begin{array}{l}\text { "Purchases are made from Society for } \\
\text { Family Health or DKT International and } \\
\text { wholesalers through a third-party } \\
\text { agreement." }\end{array}$ \\
\hline Price Setting & $\begin{array}{l}\text { "It is mainly based on the } \\
\text { supplier's quotation. } \\
\text { Manufacturers set prices, which } \\
\text { are then negotiated. UNFPA } \\
\text { handles the negotiation with the } \\
\text { manufacturers." }\end{array}$ & $\begin{array}{l}\text { "We ask for a quotation from } \\
\text { vendors at the central and national } \\
\text { level. Based on negotiation with } \\
\text { the manufacturers and in check } \\
\text { with other social-marketing } \\
\text { organizations such as DKT and the } \\
\text { prevailing market situation, we } \\
\text { send a tender through a } \\
\text { competitive process." }\end{array}$ & $\begin{array}{l}\text { "Prices are set by producers and agents. } \\
\text { We do not set prices." }\end{array}$ \\
\hline Quality Control & $\begin{array}{l}\text { "It is done in collaboration with } \\
\text { NAFDAC and complying with } \\
\text { WHO PQ, and determined } \\
\text { through the Essential Medicines } \\
\text { List (EML) committee. The quality } \\
\text { specification can be found in the } \\
\text { EML. We test the product based } \\
\text { on the manufacturers' } \\
\text { instruction." }\end{array}$ & $\begin{array}{l}\text { "It is based on WHO PQ and EML of } \\
\text { Nigeria. Company preshipment } \\
\text { assessment is conducted following } \\
\text { WHO guidelines. NAFDAC also } \\
\text { inspects and regulates on arrival. } \\
\text { Organizations have their own } \\
\text { guidelines that are drafted and } \\
\text { adopted from WHO guidelines. So, } \\
\text { quality control is done by the } \\
\text { manufacturers, local regulator, and } \\
\text { procuring organizations. }\end{array}$ & $\begin{array}{l}\text { "We check for expiration dates and only } \\
\text { the drugs on the EML are included. We } \\
\text { also rely on the reputation of suppliers, } \\
\text { e.g. SFH and DKT, and on } \\
\text { recommendations of agents or } \\
\text { manufacturers." }\end{array}$ \\
\hline
\end{tabular}

NAFDAC $=$ National Agency for Food and Drug Administration and Control. $\mathrm{PQ}=$ Prequalification.

Nigeria has a robust system in place for contraceptive procurement, pricing, and quality control across the public, private nonprofit, and private commercial sectors (Table 13). Because UNFPA procures commodities for the public system, pricing and quality control are done according to international standards. The processes for the private nonprofit system are based on the World Health Organization (WHO) standard and pricing is done through a very competitive process. The private commercial sector predominantly relies on a supply and verification system of social franchising organizations such as SFH and DKT International. Even though robust mechanisms and processes are in place, there are often reported cases of substandard and counterfeited reproductive health and FP commodities, highlighting the importance of continuous vigilance. 
TABLE 14 Procurer comments on the PVR and one-year CVR by sector

\begin{tabular}{l|l|l}
\hline Sector & \multicolumn{1}{|c}{ Comments on PVR } & \multicolumn{1}{c}{ Comments on One-Year CVR } \\
\hline Public & $\begin{array}{l}\text { "Good method for breastfeeding women." } \\
\text { "It has to be registered first. Some women would use it. } \\
\text { This will promote healthy child spacing." }\end{array}$ & $\begin{array}{l}\text { "It will add to the available methods mix." } \\
\text { "It will prevent unwanted pregnancies and } \\
\text { reduce illegal abortion. With this, most ladies } \\
\text { can complete their education." }\end{array}$ \\
$\begin{array}{l}\text { Private } \\
\text { Nonprofit }\end{array}$ & $\begin{array}{l}\text { "It [procurement and use] depends on the government. The } \\
\text { government determines what is procured." } \\
\text { "If it is really as you have described it, it looks as if it would } \\
\text { be liked by most spouses." }\end{array}$ & $\begin{array}{l}\text { "[For procurement and availability], it is the } \\
\text { same with the PVR: It depends on government } \\
\text { (willingness). It will help bring down the cases } \\
\text { of unwanted pregnancies." }\end{array}$ \\
\hline $\begin{array}{l}\text { Private } \\
\text { Commercial }\end{array}$ & $\begin{array}{l}\text { "If the public likes and asks for it, and it is not complicated } \\
\ldots \text { it will certainly be of high demand for child spacing." }\end{array}$ & $\begin{array}{l}\text { "Girls would like and use it. It will help our } \\
\text { women. Removal at users' convenience; } \\
\text { women will like it." }\end{array}$ \\
\hline
\end{tabular}

Procurers are unanimous on the utility and value-adding potential of the PVR and the one-year CVR when eventually registered and introduced in the country (Table 14). The rings would add to the mix of contraceptive methods in the country and are generally perceived as capable of improving the uptake of contraceptives (Ross and Stover 2013) and thus preventing unwanted pregnancies and enhancing healthy child spacing. However, for this to happen, according to the views of many procurers, the government should show interest by playing a leading role in contraceptive procurement and distribution. 


\section{Conclusion}

Contraceptive services and commodities are available free of charge at public health facilities in Nigeria. However, public facilities have frequent stock-outs and hence the private sector accounts for more than $60 \%$ of contraceptive provision in the country in both rural and urban settings. The government of Nigeria has committed to a goal of reaching a CPR of 36\% by 2018 and has outlined an ambitious strategy for achieving this goal. The introduction of new contraceptives to enhance contraceptive choice and address unmet need for family planning is part of the strategy. However, new product introduction often suffers from a lack of available market research and relies on hypothetical approaches to gauge consumer demand. As a new product in sub-Saharan Africa, similar challenges will be faced by the PVR. To prepare for and facilitate eventual introduction into Nigeria, we undertook this study to assess consumers' "Willingness to Pay," providers' "Willingness to Provide," and procurers' "Willingness to Procure." Findings were generated on all three aspects and are listed below.

- Prospective consumers, providers, and procurers expressed support and interest in contraceptive vaginal rings. Frequently expressed opinions were that the PVR (and the oneyear (VR) is a welcome development that would add value to the postpartum family planning landscape, broaden contraceptive options for women, enhance child spacing, and prevent unintended pregnancies.

- Consumers are willing to pay for the PVR irrespective of the sector through which they access contraceptive commodities. At a price point of US\$1.7 (N300), more than $75 \%$ of consumers are willing to pay for the PVR in the public, private nonprofit, and private commercial sectors. Willingness to pay in the public sector declines at prices over N300. However, in the private sector (nonprofit and commercial), a significant proportion of women are willing to purchase the PVR at higher prices.

- Although the price of the PVR is a determinant of consumer demand, respondents also indicated other factors such as the desire to avoid unintended pregnancy and the ability to use modern contraceptives as being important to their decision-making. The importance of wanting to avoid unwanted pregnancy is clearly reflected in the market as evidenced by the high median cost of EC pills (US\$27) in the private sector.

- Consumers are willing to pay for the one-year CVR as well. The analysis indicates a feasible price point of US $\$ 9(\mathrm{~N} 1,000)$ with a demonstrated willingness to pay across all three sectors. At this price, more than $65 \%$ are willing to pay in the public sector and more than $80 \%$ in the private nonprofit and commercial sectors.

- The potential for innovative pricing mechanisms, especially for public-sector consumers will need to be explored. The mechanism would leverage existing government subsidies so that consumers pay a small portion of the price with financing covering the rest.

- The active role of the private sector in FP provision is indicative of the possibility of utilizing a vibrant total market for the introduction of the PVR to serve its customer segments based on their levels of willingness to pay. 
- Providers across all three sectors indicated the importance of including the PVR and one-year CVR in the method mix. Their responses also highlighted the importance of orientation and education for potential providers to ensure successful integration of the rings when eventually registered.

- The procurement, pricing, and quality-assurance systems are robust in Nigeria. The PVR (and the one-year CVR), when introduced, could easily feed into the existing structures and obviate the need for establishing parallel procurement, pricing, and quality-assurance systems.

Through this study we have gained better insight into the socioeconomic determinants of product use, including the consumer's willingness to pay and also the priorities that drive the important stakeholders-providers and procurers. In terms of utilization, the results generated will inform and guide next steps about product introduction. Specifically, the findings of this study will be integrated with results from a market-segmentation exercise conducted earlier to develop a pricing model for the PVR. The price will reflect not only the cost of goods and cost of product introduction (training, educational material, marketing and branding, demand creation), but also the benefits to the health system (e.g., limited need for infrastructure and equipment, potential for multiple service outlets and health cadres). The results will also be useful to refine PVR market segmentation and tailor specific strategies for product introduction, including innovative financing approaches. 


\section{References}

Africa Progress Panel. 2015. “Power, people and planet: Seizing Africa's energy and climate opportunities. "Africa Progress Report 2015”. Accessed 30 October 2015.

http://www.africaprogresspanel.org/publications/policy-papers/2015-africa-progress-report/.

Borda, M. and W. Winfrey. 2010. "Postpartum fertility and contraception: Analysis of findings from 17 countries.” Baltimore, MD: Jhpiego.

Foreit, K.G. and J.R. Foreit. 2001. "Willingness to pay surveys for setting prices for reproductive health products and services: A user's manual." Frontiers in Reproductive Health, Population Council, Policy Project, and Futures Group International.

National Bureau of Statistics (NBS). 2012. “Nigerian poverty profile report 2010-NBS." Accessed 30 October 2015. http://www.proshareng.com/news/Nigeria\%20Economy/Nigerian-Poverty-ProfileReport-2010---NBS/16302.

National Population Commission (NPC) [Nigeria] and ICF Macro. 2009. Nigeria Demographic and Health Survey 2008. Abuja, Nigeria: NPC and ICF Macro.

National Population Commission (NPC) [Nigeria] and ICF International. 2014. Nigeria Demographic and Health Survey 2013. Abuja, Nigeria, and Rockville, MD.

Obare et al. 2014. "Assessing the potential market for a Progesterone Contraceptive Vaginal Ring (PCVR) as a new contraceptive option in sub-Saharan Africa using needs-based market segmentation." New York: Population Council.

Ross, John and John Stover. 2013. "Use of modern contraception increases when more methods become available: Analysis of evidence from 1982-2009." Global Health: Science and Practice 1(2): 203-212.

Sonalkar, S., S. Mody, S. Phillips, and M.E. Gaffield. 2013. "Programmatic aspects of postpartum family planning in developing countries: A qualitative analysis of key informant interviews in Kenya and Ethiopia," African Journal of Reproductive Health 17(3): 54-56.

Tien, M., et al. 2009. “Nigeria: Reproductive health commodity security situation analysis." Arlington, VA: USAID/DELIVER PROJECT, Task Order 1. 


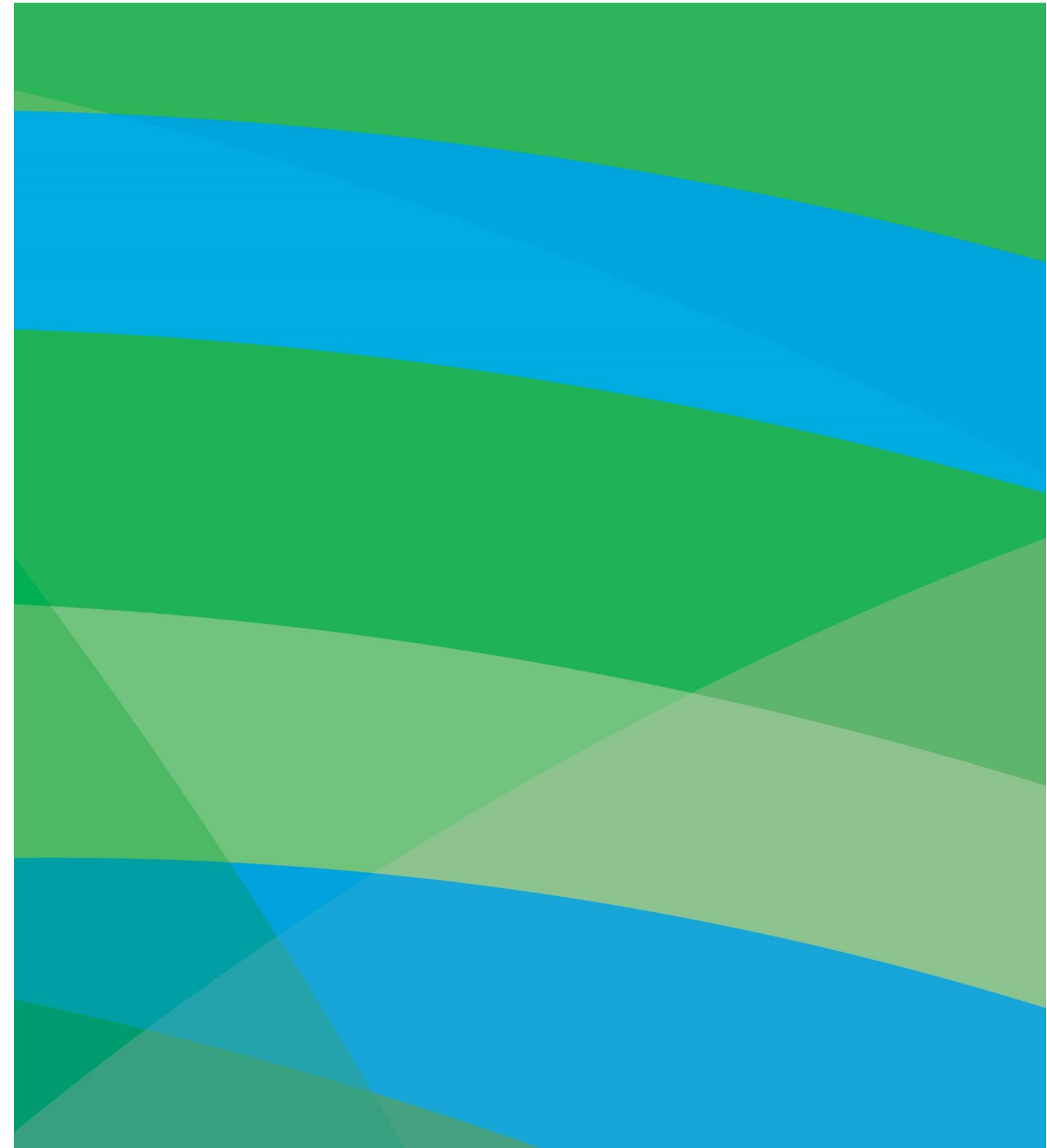

Population Council House 4, No. 16b,

\section{POPULATION} COUNCIL

Ideas. Evidence. Impact.

House 4, No. 16b,

POW Mafemi Crescent
Utako District

Abuja, Nigeria 